\title{
Climate change impacts on coastal and pelagic environments in the southeastern Bay of Biscay
}

\author{
Guillem Chust $^{1, *}$, Ángel Borja ${ }^{2}$, Ainhoa Caballero ${ }^{2}$, Xabier Irigoien $^{2}$, Jon Sáenz ${ }^{3}$, \\ Roberto Moncho ${ }^{1}$, Marta Marcos ${ }^{4}$, Pedro Liria ${ }^{2}$, Julia Hidalgo ${ }^{5}$, Mireia Valle ${ }^{2}$, \\ Victoriano Valencia ${ }^{2}$
}

\author{
${ }^{1}$ AZTI-Tecnalia, Marine Research Division, Txatxarramendi ugartea z/g, 48395 Sukarrieta, Spain \\ ${ }^{2}$ AZTI-Tecnalia, Marine Research Division, Herrera kaia portualdea z/g, 20110 Pasaia, Spain \\ ${ }^{3}$ Department of Applied Physics II, University of the Basque Country, Bilbao, Spain \\ ${ }^{4}$ IMEDEA (CSIC-UIB), Miquel Marquès, 07190 Esporles, Spain \\ ${ }^{5}$ Labein-Tecnalia, Environment Unit, C/Geldo - Parque Tecnológico de Bizkaia, Edificio 700, 48160 Derio, Spain
}

\begin{abstract}
The impacts of global climate change on the Basque coast and the pelagic systems within the southeastern Bay of Biscay are reviewed. Climate projections under greenhouse gas emission scenarios indicate that this area will experience changes in climate throughout the 21st century, including warming of surface air (especially heat wave episodes), intensification of extreme daily rainfall $(10 \%)$, warming of the upper $100 \mathrm{~m}$ of the ocean layer $\left(1.5\right.$ to $\left.2.05^{\circ} \mathrm{C}\right)$, and sea level rise (SLR; 29 to $49 \mathrm{~cm}$ ). Observations made in the bay throughout the 20th century for air temperature and mean sea level are in agreement with these projections. Trends in ocean-climatic historical observations within the area, including sea temperature, precipitation, upwelling/downwelling, turbulence and wave climate, are also reviewed. The main impacts on the coast are expected to be from SLR, especially in low-lying areas (mostly urbanised) within estuaries. Sandy beaches are also expected to undergo significant mean shoreline retreats of between 25 and $40 \%$ of their width. As the sea level rises, the natural migration of saltmarshes and intertidal seagrasses landward will be constrained, in most cases, by existing anthropogenic fixed boundaries. Empirical relationships between the distribution and dynamics of the long-term biological measures (plankton, primary production, benthos, and fisheries) on the one hand, and ocean-climatic variability on the other, indicate that pelagic and coastal water ecosystems will be affected by ocean warming, increased stratification, shifts in anomaly patterns and streamflow regimes. The largest uncertainties are associated with the lack of downscaled projections within the bay on ocean circulation, ocean-meteorological indices, wave climate and ocean acidification.
\end{abstract}

KEY WORDS: Climate change $\cdot$ Bay of Biscay $\cdot$ Basque Country $\cdot$ Coast $\cdot$ Sea level $\cdot$ Temperature $\cdot$ Precipitation $\cdot$ Saltmarsh $\cdot$ Review

Resale or republication not permitted without written consent of the publisher

\section{INTRODUCTION}

According to the projections of global climate models provided by the Intergovernmental Panel on Climate Change (IPCC) Fourth Assessment Report (AR4, IPCC 2007), under future greenhouse gas (GHG) emission scenarios, a warming of the mean surface air and sea of the Bay of Biscay (for locations, see Fig. 1a), especially in the upper layers of the water column, is expected by the end of the $21^{\text {st }}$ century (Meehl et al. 2007). A direct consequence of seawater warming is the thermal expansion of oceans, together with a rise in the thermosteric mean sea level (Reid et al. 2009), which may affect the coastal zones of the bay. Extensive literature covers future threats of global climate change expected for the next century over the world oceans (e.g. Reid et al. 2009) and coasts (see reviews by Nicholls et al. 2007 and FitzGerald et al. 2008). However, the resolution of all of the atmosphere-ocean general circulation models (AOGCMs) is insufficient for predicting changes in 
ocean current circulation in the southeastern Bay of Biscay (Fig. 1). Likewise, the location of the Iberian Peninsula, within a transitional zone between oceanic temperate and the dry subtropical climate (Barry \& Chorley 2003), makes it difficult to predict the future climate regime (especially precipitation) over the area. Downscaling data from global climate models to represent smaller areas is important in obtaining accurate climate projections at regional scales (e.g. Penduff et al. 2010), and for defining local adaptation strategies to climate change.

The vulnerability of the Basque coast and its marine environment to potential change in present climate regimes is increased by the demographic pressure, the overexploitation of resources and the high human use of the marine space. The coastal zone supports $60 \%$ of the overall population of the Basque Country (2.1 million inhabitants) and $33 \%$ of the industrial activities (Cearreta et al. 2004), including other activities, such as fisheries, tourism and renewable energies (Galparsoro et al. 2010). This coast is dominated by rocky substrata

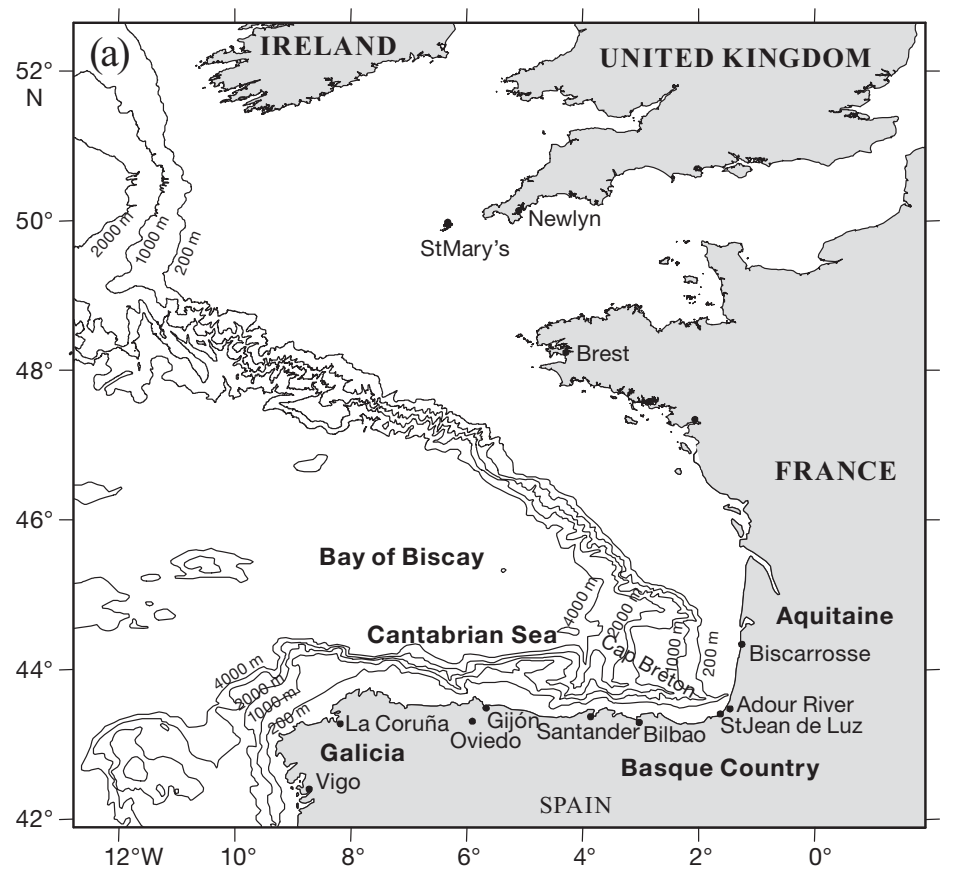

with vertical cliffs intercalated with small estuaries with sandy beaches; it is exposed to the prevailing wind and wave directions ( $\mathrm{N}$ and $\mathrm{NW}$ ), produced by the evolution of the North Atlantic low pressure systems (González et al. 2004). Hence, the sea cliffs and hilly relief limit and confine the extent of the sandy beaches, saltmarshes, urban settlements and industrial zones along the coast. Concerning specifically the environmental and biological conservation of intertidal systems, the demographic and urban pressure on the Basque coast has led to extensive loss, squeeze and degradation of the littoral habitats during the 20th century (Chust et al. 2009). Similarly, fishing stocks within the bay can also be vulnerable to climate change (Clemmesen et al. 2007), especially when they are overexploited (Planque et al. 2010). An efficient adaptation of these human activities, in response to global climate change, requires an integrated understanding of regional climatic changes to local impacts on habitats and species.

Hence, the objective of this paper was to review the scientific literature on climate change impacts within the Basque coastal systems and the pelagic environment, within the regional context of the Bay of Biscay (Fig. 1). An integrated 'stateof-the-art' review of the climate change in the area, based upon the main studies undertaken to date, is presented. Climatic observations throughout the recent past (most within the 20th century), together with the regional climate change scenarios for the 21st century, are reviewed. Subsequently, the anticipated impacts according to these scenarios on coastal systems (sandy shores, estuaries, saltmarshes and biodiversity) and on the pelagic environment (primary production and fisheries) are presented, together with the observed trends and variability throughout the past decades. The main conclusions are then presented, summarising the review.

Fig. 1. (a) Bay of Biscay and (b) Basque Country. All locations cited in the text and the most important features are shown

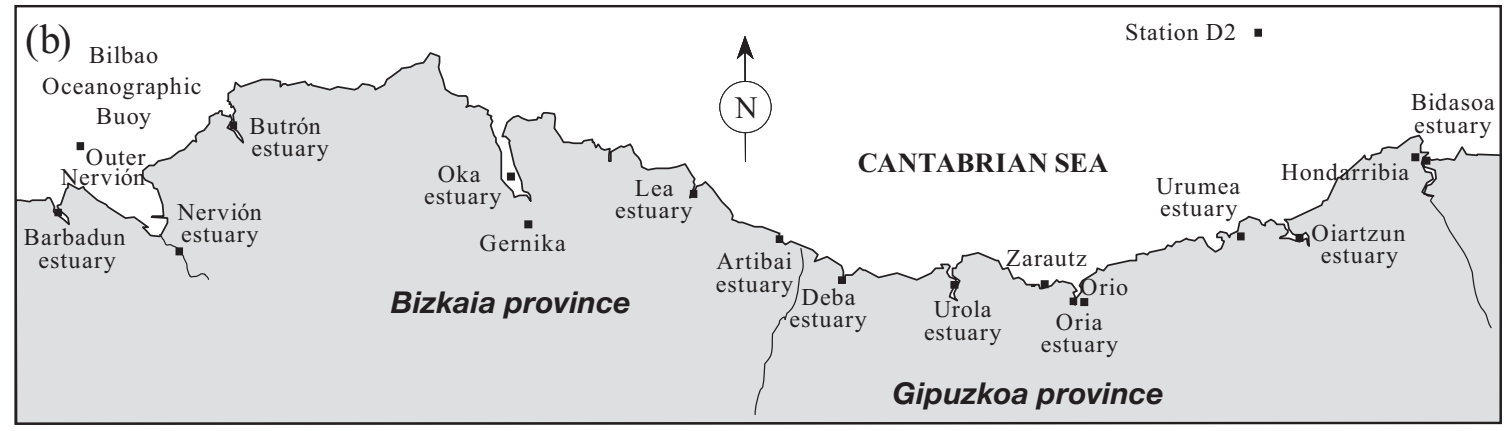




\section{CLIMATIC VARIABILITY AND TRENDS}

\subsection{Air temperature and atmospheric variability}

\subsubsection{Observations in the 20th century}

Brunet et al. (2007) used the Spanish Daily Adjusted Temperature Series (SDATS) dataset to identify the main patterns of spatial and temporal variability of daily maximum and minimum temperature over Spain. A very important latitudinal gradient of variability exists over the Iberian Peninsula. During the period 1901-2005, the trend in the annual temperature of the northern part of the Iberian Peninsula was about $0.13^{\circ} \mathrm{C}$ decade $^{-1}\left(\mathrm{dec}^{-1}\right)$, with a $95 \%$ confidence interval lying between 0.09 and $0.16^{\circ} \mathrm{C} \mathrm{dec}^{-1}$. This trend in the annual temperature is much higher during the last part (1973-2005) of the instrumental period, with a central estimate of the trend given by $0.51^{\circ} \mathrm{C} \mathrm{dec}^{-1}$, with a $95 \%$ confidence interval of $0.36-0.69^{\circ} \mathrm{C} \mathrm{dec}^{-1}$. The analysis performed in terms of percentiles showed an increase in the number of hot days and a decrease in the number of cold days, with a $99 \%$ confidence level (Brunet et al. 2007). Other studies (Sáenz et al. $2001 \mathrm{~b})$ showed similar trends $\left(0.2-0.3^{\circ} \mathrm{C} \mathrm{dec}^{-1}\right)$ during winter, for a denser set of stations over land locations along the Cantabrian coast (reference period 1950-1996).

Aravena et al. (2009a) used monthly anomalies of temperatures and teleconnection indices (1997-2006) and found a significant correlation between air temperature over the Basque Country and the North Atlantic Oscillation (NAO) index. This result is not consistent with previous results obtained by other researchers who focused upon longer winter temperature series (Pozo-Vázquez et al. 2001, Sáenz et al. 2001a, Castro Díez et al. 2002, Frías et al. 2005). Therefore, it seems that the relationship between the NAO and the temperature over the area is dependent upon season or the length of the time series being analysed.

Following Sáenz et al. (2001b), winter temperature over southwestern Europe is dependent on the variability of the sensible heat fluxes under average circulations, with eddy (baroclinic) heat fluxes playing no significant role in the temperature variability. Conversely, variability in precipitation is driven by variability in baroclinic disturbances over the area and the structure of the Atlantic storm track. This explains the different sensitivity of temperature and precipitation to teleconnection indices over the area. However, recent studies have emphasised that a small fraction of the predictability of winter precipitation over the Cantabrian coast might depend in a non-linear way on the state of the El Niño Southern Oscillation (ENSO) events (Frías et al. 2010).

\subsubsection{Projections for the 21 st century}

Based upon future projections of climate at a $50 \times$ $50 \mathrm{~km}^{2}$ horizontal resolution, provided by the EU project PRUDENCE (Christensen et al. 2007a) for different IPCC emissions scenarios (Nakicenovic et al. 2000), Abanades et al. (2007) analysed the expected change of several climatic variables. They showed that the seasonal mean temperature anomaly, for the period 2071-2100 compared to the period 1961-1990, over the Basque Country will vary from 5 to $7^{\circ} \mathrm{C}$ in summer and 3 to $4^{\circ} \mathrm{C}$ in winter for the $\mathrm{A} 2$ scenario. In the coastal area, these values will reduce to $2^{\circ} \mathrm{C}$ for the $\mathrm{A} 1$ scenario, both in summer and winter, and $3^{\circ} \mathrm{C}$ in summer and $1^{\circ} \mathrm{C}$ in winter for the $\mathrm{B} 1$ scenario. Depending upon the season, the maximum temperature anomalies will vary between 1.5 and $2.5^{\circ} \mathrm{C}$ in winter and 4.5 to $7^{\circ} \mathrm{C}$ in summer. During the last third of the 21 st century, the increase of the monthly maximum temperature is expected to be $1.5^{\circ} \mathrm{C}$ at the coast and $3.5^{\circ} \mathrm{C}$ inland. The increase in monthly minimum temperatures (Tmin) during the same period will probably range between 1 and $1.5^{\circ} \mathrm{C}$ at the coast and 2.5 to $3^{\circ} \mathrm{C}$ inland.

Abanades et al. (2007) identified a positive trend in the daily thermal oscillation (Tmax - Tmin), with daily maximum temperatures increasing more than the mean and minimum temperatures. In the last third of the century, for the A2 scenario, the increase in maximum temperatures will be $0.5^{\circ} \mathrm{C}$ higher than those of the mean temperatures, whereas daily minimum temperatures will be $0.4^{\circ} \mathrm{C}$ lower than those of the mean temperatures. These changes will be weaker during winter and more pronounced during spring and summer, particularly along the southern parts of the Cantabrian coast.

The $2 \mathrm{~m}$ air temperature and humidity outputs in the Basque Country have been studied (authors' unpubl. data) using 6 Regional Climate Models (RCMs) from the ENSEMBLES project (Hewitt 2005), which performed simulations for Europe at $25 \times 25 \mathrm{~km}^{2}$ horizontal resolution for the A1B emission scenario (Nakicenovic et al. 2000). The control period was 1978-2000. In winter, the 10th percentile of the minimum temperature showed a positive trend (Fig. 2a) with an increase of up to $3^{\circ} \mathrm{C}$ at the end of the century with a maximum standard deviation of $0.9^{\circ} \mathrm{C}$. The range in the 10 th percentile of minimum temperatures within the control period is -5.5 to $-2.0^{\circ} \mathrm{C}$ i in turn, for the period $2070-$ 2099 , this value will range from -3.5 to $1.0^{\circ} \mathrm{C}$. All of the models showed a $50 \%$ decrease in the number of frost days (Tmin $<0^{\circ} \mathrm{C}$ ) at the end of the century. Consequently, both the duration and frequency of cold waves will decrease. Cold-wave episodes (6 consecutive days having temperatures lower than the seasonal temperature for the control period by $5^{\circ} \mathrm{C}$ ) are expected to dis- 


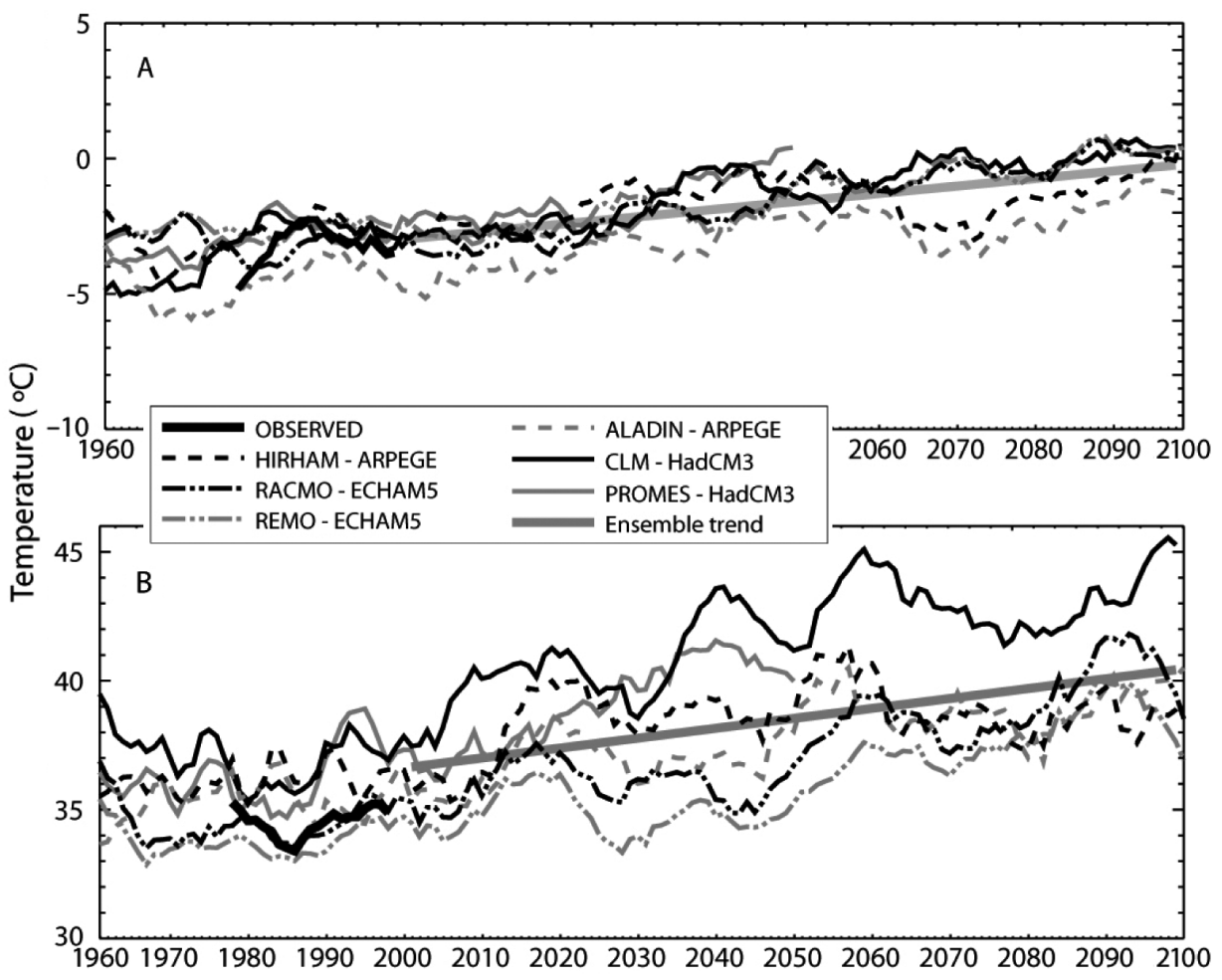

Fig. 2. Time-series of (A) 10th percentile of winter minimum temperature and (B) 90th percentile of summer maximum temperature for 6 regional climate models compared with observations during the control period (1978-2000)

appear beyond 2020. In summer, a positive trend of the 90th percentile of daily maximum temperature is expected (Fig. 2b), with an increase of up to $3^{\circ} \mathrm{C}$ and a maximum standard deviation of $1.4^{\circ} \mathrm{C}$. The range of the 90th percentile of maximum temperatures in the control period is 34 to $38^{\circ} \mathrm{C}$; for the last 3 decades it was 37 to $45^{\circ} \mathrm{C}$. Heat-wave episodes $(6$ consecutive days having temperatures higher than the seasonal temperature for the control period by $5^{\circ} \mathrm{C}$ ), will increase in duration and, to a lesser extent, occurrence. In the control period, only $12 \%$ of the days in the summer could be considered as a heat wave episode. Nevertheless, the rate of change is likely to increase between 2020 and 2050, when the number of heat waves is expected to increase to $16 \%$, with further increases to $22 \%$ by the end of the century.

\subsection{Mean and extreme precipitation}

\subsubsection{Observations in the 20th century}

Global warming could cause a regime change in average and extreme rainfall at regional and local levels (Allan \& Soden 2008, O'Gorman \& Schneider 2009). However, due to the high natural variability of precipitation, it is difficult to observe these changes during the short time series of available observations
(Rodrigo et al. 1999). Over the Iberian Peninsula, total annual precipitation generally showed no significant changes during the 20th century, except for the most southern areas (deCastro et al. 2005). During the second half of that century, some northern inland areas showed a decrease in annual rainfall, for example at the station of Oviedo $\left(-7 \pm 3\right.$ [SE] $\mathrm{mm} \mathrm{yr}^{-1}$; Serrano et al. 1999, Mossmann et al. 2004, De-Luis et al. 2008), especially in spring and winter (Lopez-Bustins et al. 2008; Table 1). The decrease in rainfall is particularly marked in March (Serrano et al. 1999, Mossmann 2002), as in the rest of western Europe (Kiely et al. 1998), and could be due to an increase in the NAO index (Bárdossy \& Caspary 1990, Hurrell 1995), since it causes a decrease in the frequency of Atlantic lowpressure systems crossing southern Europe during March (Visbeck et al. 2001, Mossmann 2002). However, this was not observed in the Basque Country, where mean rainfall did not change between 1961 and $2000\left(-1 \pm 3 \% \mathrm{dec}^{-1}\right.$; Fig. 3), a result derived using monthly and daily data from 132 meteorological stations (Moncho et al. 2009). These results are consistent with a similar analysis undertaken by Trigo et al. (2008). The NAO is probably not the main factor affecting precipitation over the northern coast of the Iberian Peninsula (Trigo et al. 2008, Aravena et al. 2009a), particularly during the winter season (Sáenz et al. 2001c). 
Table 1. Changes in regimes of precipitation within the Iberian Peninsula and northern Europe for the 20th century. Changes are statistically significant ( $5 \%$ significance level) except where noted. NS: not significant

\begin{tabular}{|lcccl|}
\hline Location & Period & Precipitation & Observed change & Source \\
\hline Igeldo & $1951-1995$ & Annual & $\mathrm{NS}$ & Serrano et al. (1999) \\
Oviedo & $1921-1995$ & Annual & $-7 \pm 3 \mathrm{~mm} \mathrm{yr}^{-1}$ & Serrano et al. (1999) \\
Basque Country & $1961-2000$ & Annual & $-1 \pm 3 \%$ decade $^{-1}$ (NS) & Moncho et al. (2009) \\
Basque Country & $1961-2000$ & Winter and spring & $-0.3 \pm 0.6 \%$ decade ${ }^{-1}$ (NS) & Moncho et al. (2009) \\
Iberian Peninsula & $1958-2000$ & Winter & $<0$ (NS) & Lopez-Bustins et al. (2008) \\
Northern Spain & $1958-2000$ & Winter & $<0$ & Lopez-Bustins et al. (2008) \\
Northern Spain & $1961-1990$ & September & $<0$ & Mosmann et al. (2004) \\
Northern Europe & $1901-2000$ & Extreme & $+6 \pm 4 \%$ & Mokhov et al. (2005), Khon et al. (2007) \\
Iberian Peninsula & $1958-1997$ & Extreme & $<0$ & Gallego et al. (2006) \\
\hline
\end{tabular}

Regarding extreme events, a significant increase $(4$ to $8 \%$ ) in heavy rainfall over the 20th century has been observed in northern Europe (Mokhov et al. 2005, Khon et al. 2007; see Table 1). Over the Iberian Peninsula, some studies have reported a slight tendency to an increase in light-rain days and a decrease in heavyrain days for observatories located over the region (Gallego et al. 2006), together with an increase in dry spells in autumn and a decrease in summer. However, reanalysis of climate showed no significant changes over the Iberian Peninsula, revealing discrepancies between the different reanalyses (Zolina et al. 2004).

\subsubsection{Projections for the 21 st century}

According to different regional projections of climate change for the 21st century, changes in the mean and extreme precipitation regimes are expected over most

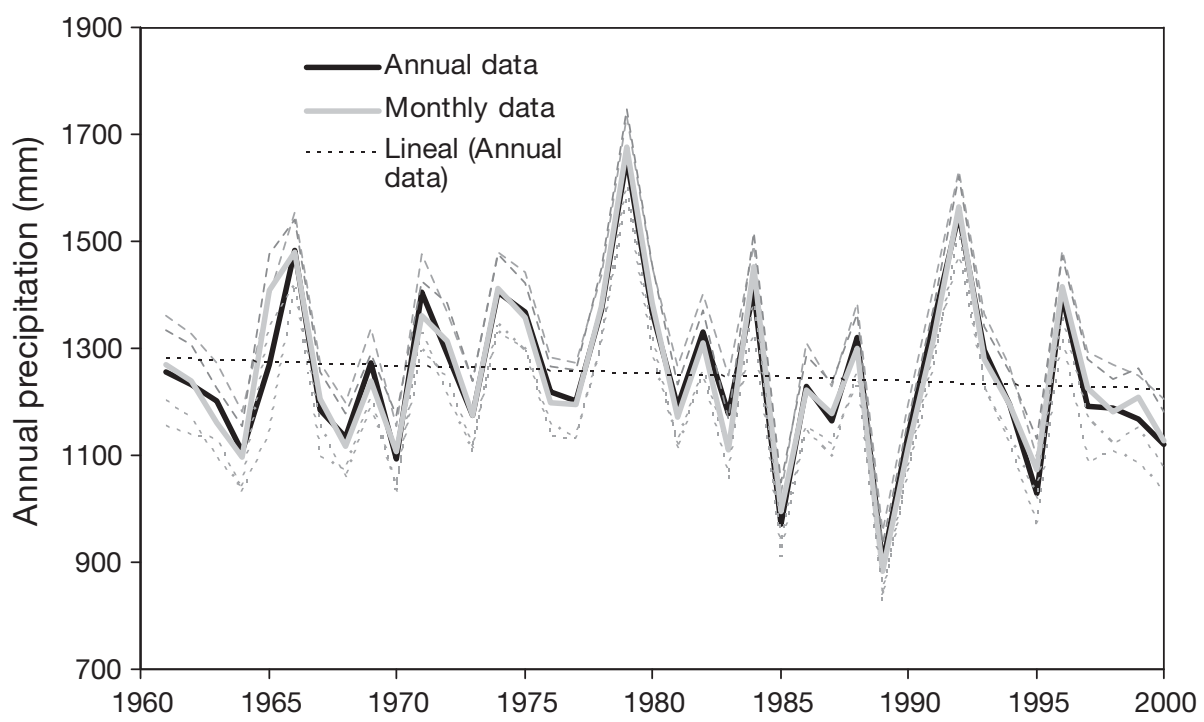

Fig. 3. Time-series of annual precipitation in the Basque Country for 1961-2000, reconstructed with monthly and annual available data. Grey dashed lines: 95\% confidence interval. Modified after Moncho et al. (2009) of Europe (Christensen et al. 2007b), with an annual precipitation increase (10 to $40 \%$ ) in northern Europe, and decreases (10 to $20 \%$ ) in the Mediterranean basin. Over the northern Iberian Peninsula, a decrease in annual rainfall of 10 to $30 \%$ is expected according to the A2 scenario, and 15 to $20 \%$ under the A1B scenario (Rummukainen et al. 2004, Christensen et al. 2007b), with high uncertainty (Tapiador et al. 2007). The average summer rainfall for 2070-2100 will decline over most of Europe, being more important in France, Spain and Portugal (25 to 75\%; Déqué et al. 2007, Goubanova \& Li 2007). In the south of Europe, a decrease in the average rainfall in winter and spring is also expected (Goubanova \& Li 2007, De-Luis et al. 2008).

The projections for 2070-2100 in intense precipitation indicate a significant increase over almost all European regions, even where the average precipitation is expected to decrease (Semenov \& Bengtsson 2002, Semmler \& Jacob 2004, Goubanova \& Li 2007).

However, for the Iberian Peninsula there is no consensus on the changes in extreme precipitation for 2070-2100. On the one hand, Semmler \& Jacob (2004) predicted a decrease of $50 \%$ in extreme rainfall within return periods of 10 and $20 \mathrm{yr}$, compared to 1961-1990. However, Goubanova \& Li (2007) found an increase of $10-20 \%$ for extreme rainfall (30 yr return period) by the 21st century, in comparison to the period 1970-1999. The location of the Iberian Peninsula within a transitional climate regime between oceanic temperate and the dry subtropical climate (Barry \& Chorley 2003) makes it difficult to predict future rainfall over the area. 
For the Basque Country, Moncho (2009) used 4 RCMs (METNO-HIRHAM, UCLM-PROMES, KNMIRAKMO2 and CNRM-RM4.5), under the A1B scenario, extracted from the ENSEMBLES project (Niehörster et al. 2008), to assess rainfall projections throughout the 21 st century. The average of the simulated trends for the period 1961-2050, according to the calibrated climate models, gives a slight decrease $(-0.7 \pm 0.3 \%$ $\left.\mathrm{dec}^{-1} ; \mathrm{p}<0.05\right)$. With a return period of $50 \mathrm{yr}$ for a meteorological station on average, the 2 models (METNO and UCLM) that best fit the 1961-2000 reference period show an increase of $12 \pm 1 \%$ in daily rainfall for the period 2001-2050, with respect to 19612000. The KNMI model projects an increase in extreme rainfall for the period from $2051-2100$ of $7.7 \pm 0.7 \%$. Thus, these results suggest that extreme precipitation over the Basque Country may be expected to increase by around $10 \%$ throughout the 21 st century. The decrease in the mean precipitation in the Basque Country for the 21st century, together with the increase in the extreme regime, could be due to increased influence of the Mediterranean by the expansion of the Hadley cell (Hu \& Fu 2007, Lu et al. 2007).

\subsection{Sea temperature}

\subsubsection{Observations in the 20th century}

A great part of the heat excess produced in the atmosphere in the 20th century, as a result of anthropogenic activities and from natural events, has been exchanged with the ocean; this is due to the high specific heat of water. In the world ocean, the mean temperature from the surface to a $700 \mathrm{~m}$ depth has increased $0.17^{\circ} \mathrm{C}$ between 1969 and 2008 (Levitus et al. 2009). This temperature rise has not been geographically homogeneous. In particular, the temperature increase that occurred in the Atlantic Ocean $\left(0.30^{\circ} \mathrm{C}\right)$ within the 1969-2008 period is more than twice that observed in the Indian $\left(0.11^{\circ} \mathrm{C}\right)$ or Pacific Oceans $\left(0.12^{\circ} \mathrm{C}_{i}\right.$ Levitus et al. 2009).

Within the Bay of Biscay, the sea surface tempera-

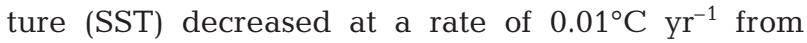
1867-1910; subsequently, it began to increase until

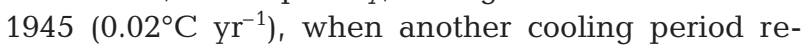

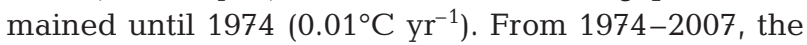
temperature increased at a rate of $0.02^{\circ} \mathrm{C} \mathrm{yr}^{-1}$ (deCastro et al. 2009; Table 2). Based on different sources of measurements, Koutsikopoulos et al. (1998) found that between 1972 and 1993, the Bay of Biscay SST showed

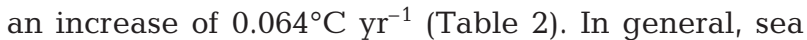
temperature is highly dependent upon spatial and temporal scales. Besides the long-term trends, sea temperature follows its own natural cycles (e.g. daily and seasonal cycles, $11 \mathrm{yr}$ cycle of solar activity, $18.6 \mathrm{yr}$ lunar nodal cycle). Therefore, it is possible to observe opposing trends when different time periods are considered. In addition, when longer time series are considered, natural cycles can be determined and removed from the time series in order to compute the long-term change. With regard to the spatial variability, Koutsikopoulos et al. (1998) concluded that within the Bay of Biscay and for the analysed time period, the highest SST increase occurred in the southeastern part. Different results were obtained by Gómez-Gesteira et al. (2008) for the period 1985-2005. In this case, the SST warming rate was higher to the north, being the highest in the northwestern Bay of Biscay.

For the southeastern Bay of Biscay, the SST time series recorded on a daily basis at the Aquarium of San Sebastián (see Fig. 1b) for the period 1947-2001 indicates a decreasing trend in the mean annual temperature; this is due to the warm periods at the end of the 1940s and the 1960s (Borja et al. 2000). However, Koutsikopoulos et al. (1998), investigating a series com-

Table 2. Annual mean rates of sea surface temperature (SST) within the Bay of Biscay, according to different locations, methods and authors (for locations, see Fig. 1). All measurements at surface depth, except santander (200 to 1000 m). CTD: conductivity, temperature and depth casts

\begin{tabular}{|c|c|c|c|c|}
\hline Location & Time period & Method & $\begin{array}{c}\text { Rate } \\
\left({ }^{\circ} \mathrm{C} \mathrm{yr}^{-1}\right)\end{array}$ & Source \\
\hline Open water of & $1867-1910$ & Satellite and reconstructed SST & -0.01 & deCastro et al. (2008b) \\
\hline \multirow{4}{*}{ Bay of Biscay } & 1910-1945 & Satellite and reconstructed SST & 0.02 & deCastro et al. (2008b) \\
\hline & $1945-1974$ & Satellite and reconstructed SST & -0.01 & deCastro et al. (2008b) \\
\hline & $1974-2007$ & Satellite and reconstructed SST & 0.02 & deCastro et al. (2008b) \\
\hline & $1972-1993$ & Vessels and meteorological buoys & 0.064 & Koutsikopoulos et al. (1998) \\
\hline San Sebastián & $1947-1977$ & Thermometer & -0.023 & $\begin{array}{l}\text { González et al. (2008); } \\
\text { Goikoetxea et al. (2009) }\end{array}$ \\
\hline San Sebastián & $1977-2007$ & Thermometer & 0.026 & $\begin{array}{l}\text { González et al. (2008); } \\
\text { Goikoetxea et al. (2009) }\end{array}$ \\
\hline Station D2 & $1986-2008$ & CTD & 0.01 & Revilla et al. (2010) \\
\hline Santander & 1992-2003 & CTD & $0.02-0.03$ & González-Pola et al. (2005) \\
\hline
\end{tabular}


mencing in the 1970s cool period and extending until 1993, found an increasing temperature trend for the southeastern Bay of Biscay. Of several SST time series, the monthly and seasonal analyses indicate increasing trends for 1971-1998, or for some specific sub-periods such as 1991-1995 (Lavín et al. 1998), 1986-1990 (Valencia 1993) and 1986-2003 (ICES 2004). This pattern shows that increasing trends are related more to mild winter SST periods than to very high summer SST values (Koutsikopoulos et al. 1998, Borja et al. 2000). As for seasonal variability, the highest temperature rise $\left(0.08^{\circ} \mathrm{C} \mathrm{yr}^{-1}\right)$, corresponding to the $1985-2006$ period, was observed in spring (deCastro et al. 2009). Additionally, recent studies have revealed an SST increase over the last 3 decades in San Sebastián and at another station (D2) also located on the continental shelf of the southeastern Bay of Biscay. The SST time series recorded in San Sebastián reflects a decrease of $0.23^{\circ} \mathrm{C}$ from 1947-1977, together with an increase of $0.026^{\circ} \mathrm{C}$ $\mathrm{yr}^{-1}$ from 1977-2007 (González et al. 2008, Goikoetxea et al. 2009, Table 2). At the D2 offshore station (see Fig. 1b), the SST from 1986-2008 showed an increase of $0.01^{\circ} \mathrm{C} \mathrm{yr}^{-1}$ (Revilla et al. 2010; Table 2).

In relation to the temperature of the intermediate waters of the southeastern Bay of Biscay, measured off the coast of Santander (see Fig. 1a), the Eastern North Atlantic Central Water and the Mediterranean Water

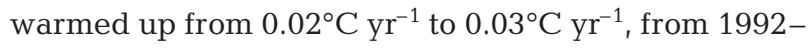
2003 (González-Pola et al. 2005, Table 2).

\subsubsection{Projections for the 21 st century}

According to the AOCGMs, global ocean warming is expected to evolve more slowly than increases in global mean surface air temperature (Meehl et al. 2007). In particular, warming in the ocean will progress from near the surface and in the northern mid-latitudes early in the 21st century, to gradual penetration downward during this century. In the Bay of Biscay, Chust et al. (2010) estimated the future sea temperature trends (from the surface to $100 \mathrm{~m}$ depth), using the outputs from a set of selected AOGCMs for this region, under 3 different scenarios. Thus, under the more optimistic scenario, the temperature will increase at a rate of $0.003^{\circ} \mathrm{C} \mathrm{r}^{-1}$ during the 21st century. This scenario (committed scenario), which assumes a GHG concentration constant at the levels existing since 2000, is not realistic, since the emission of GHGs has increased since 2000; however, it indicates that the sea temperature will continue to increase even if the emissions cease. The A1B scenario considers an increase in the GHG concentration during the first half of the century and a decrease during the second half. In this scenario, the expected increase will be on the order of $0.015^{\circ} \mathrm{C}$ $\mathrm{yr}^{-1}$ for the period 2001-2099 (Fig. 4). In contrast, the A2 scenario does not anticipate an increasing use of more efficient technologies during the second half of the century; as a consequence, the concentration of the GHGs will increase throughout the 21st century, together with the sea temperature $\left(0.02^{\circ} \mathrm{C} \mathrm{yr}^{-1}\right.$; Fig. 4). These projections are subjected to some uncertainties arising from different sources, i.e. the remarkably different results depending on the selected AOGCM. Nevertheless, if a partially or totally anthropogenic origin of the rise in ocean temperature over the last decades is assumed, this is a first step in the prediction of future temperature within the area of study.

\subsection{Sea level rise}

\subsubsection{Observations in the 20th century}

Long-term global mean sea level variations are attributed to steric changes caused by variations in the thermohaline properties of the ocean and to mass addition or subtraction by changes in water reservoirs, mainly ice sheets, glaciers and ice caps. Based upon historical tide gauge records, the global mean SLR rate during the 20th century has been estimated to be $1.7 \pm$ $0.5 \mathrm{~mm} \mathrm{yr}^{-1}$ (Church \& White 2006). More recent estimates have obtained an averaged sea level trend of $1.6 \pm 0.2 \mathrm{~mm} \mathrm{yr}^{-1}$ for the period 1961-2003; of this, $0.8 \pm 0.1 \mathrm{~mm} \mathrm{yr}^{-1}$ is caused by thermal expansion (Domingues et al. 2008), although uncertainties remain

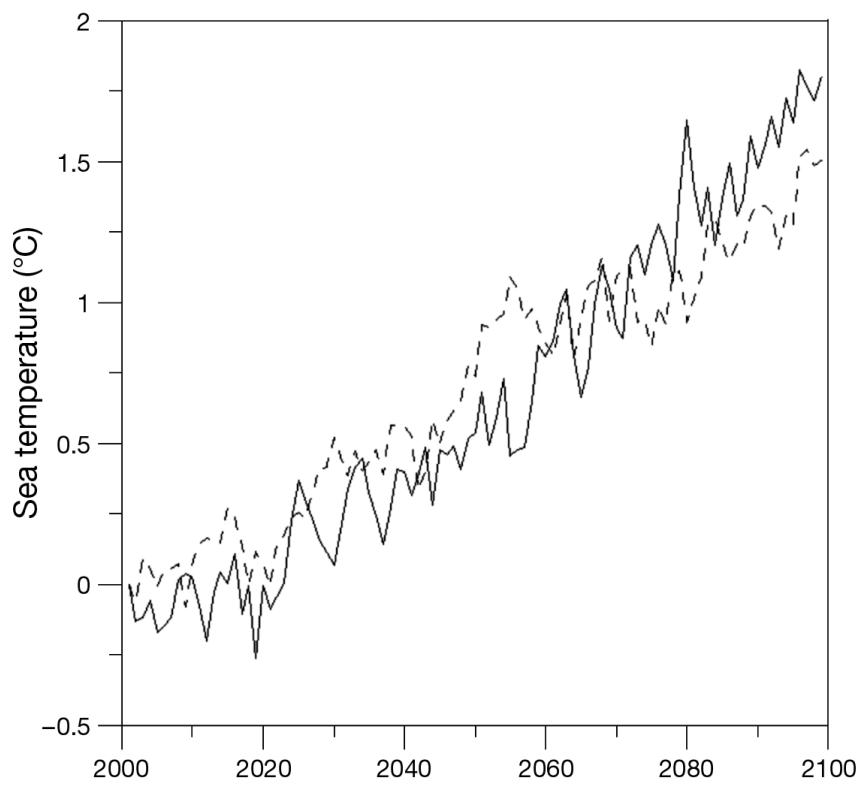

Fig. 4. Projected annual sea temperature (upper $100 \mathrm{~m}$ layer) for the 21st century under the special report on emissions scenarios (SRES) A1B (solid line) and SRES A2 (broken line). Modified from Chust et al. (2010) 
Table 3. Annual mean rates of sea level rise within the Bay of Biscay and southwestern UK, according to different locations, methods and authors (for locations, see Fig. 1)

\begin{tabular}{|lcccc|}
\hline Location & Method & $\begin{array}{c}\text { Time } \\
\text { period }\end{array}$ & $\begin{array}{c}\text { Rate }( \pm \text { SE) } \\
\left(\mathrm{mm} \mathrm{yr}^{-1}\right)\end{array}$ & Source \\
\hline Vigo & Tide gauge & $1943-2001$ & $2.91 \pm 0.09$ & Marcos et al. (2005) \\
La Coruña & Tide gauge & $1943-2001$ & $2.51 \pm 0.09$ & Marcos et al. (2005) \\
Santander & Tide gauge & $1943-2004$ & $2.08 \pm 0.33$ & Chust et al. (2009) \\
Santander & Tide gauge & $1993-2004$ & $2.67 \pm 3.24$ & Chust et al. (2009) \\
Bilbao & Tide gauge & $1993-2005$ & $2.98 \pm 1.08$ & Chust et al. (2009) \\
Socoa/St Jean de Luz & Tide gauge & $1942-2006$ & $2.09 \pm 0.42$ & Chust et al. (2009) \\
Brest & Tide gauge & $1890-1980$ & $1.3 \pm 0.5$ & Wöppelmann et al. (2006) \\
Brest & Tide gauge & $1980-2004$ & $3.0 \pm 0.5$ & Wöppelmann et al. (2006) \\
Newlyn & Tide gauge & $1915-2005$ & $1.77 \pm 0.12$ & Araújo \& Pugh (2008) \\
St. Mary's & Tide gauge & $1968-2006$ & $1.73 \pm 0.52$ & Haigh et al. (2009) \\
Open water of Bay of Biscay & Satellite altimeters and tide gauge & $1993-2002$ & $3.09 \pm 0.21$ & Marcos et al. (2007) \\
Open water of Bay of Biscay & Satellite altimeters & $1993-2005$ & 2.7 & Caballero et al. (2008) \\
Basque coast & Foraminifera-based transfer functions & 20th century & 2.0 & Leorri et al. (2008) \\
Basque coast & Foraminifera-based transfer functions & 20th century & 1.9 & Leorri \& Cearreta (2009) \\
& & & &
\end{tabular}

regarding the contribution of the mass changes (Cazenave et al. 2009). The sea level changes are regionally variable, as has been shown on the basis of the analyses of tide gauge records (e.g. Douglas 1992, Lambeck 2002, Church et al. 2004) and from the global coverage of satellite altimetry in open oceans (Bindoff et al. 2007). In some regions, the SLR is higher than the global mean; in others, a fall in sea level is occurring (Cazenave \& Nerem 2004).

Within the Bay of Biscay, several studies based upon tide gauge records have consistently shown a rise in sea level (Table 3, and see Fig. 1a for locations): $2.12 \mathrm{~mm} \mathrm{yr}^{-1}$ at Santander, $2.51 \mathrm{~mm} \mathrm{yr}^{-1}$ at La Coruña and $2.91 \mathrm{~mm}$ $\mathrm{yr}^{-1}$ at Vigo, during the period 19432001 (Marcos et al. 2005); $1.77 \pm$ $0.12 \mathrm{~mm} \mathrm{yr}^{-1}$ during 1915-2005 at Newlyn, southwestern UK (Araújo \& Pugh 2008), and $1.73 \pm 0.52 \mathrm{~mm} \mathrm{yr}^{-1}$ during 1968-2006 at St. Mary's, southwestern UK (Haigh et al. 2009). The long tide gauge data series for Brest, located within the northern part of the Bay of Biscay (Fig. 1a), has also revealed that SLR is accelerating (an SLR of $1.3 \pm 0.5 \mathrm{~mm} \mathrm{yr}^{-1}$ between 1890 1980 , and of $3.0 \pm 0.5 \mathrm{~mm} \mathrm{yr}^{-1}$ during 1980-2004; Wöppelmann et al. 2006). Such acceleration is in agreement with the rates obtained in the open waters of the Bay of Biscay since 1993, when operational satellite altimetry commenced, by Marcos et al. (2007) (3.09 $\mathrm{mm} \mathrm{yr}^{-1}$ during 1993-2002) and Caballero et al. (2008) (2.7 $\mathrm{mm} \mathrm{yr}^{-1}$ dur- ing 1993-2005). Along the Basque coast, indirect approaches, such as foraminifera-based transfer functions (Pascual \& Rodríguez-Lázaro 2006), have identified a rate of rise of $2 \mathrm{~mm} \mathrm{yr}^{-1}$ during the 20th century (Leorri et al. 2008, Leorri \& Cearreta 2009). These results are consistent with the tide gauge records over that area according to the periods of time (St. Jean de Luz: $2.09 \mathrm{~mm} \mathrm{yr}^{-1}$ from 1942-2006; Bilbao: $2.98 \mathrm{~mm}$ $\mathrm{yr}^{-1}$ from 1993-2005; Chust et al. 2009; Fig. 5).

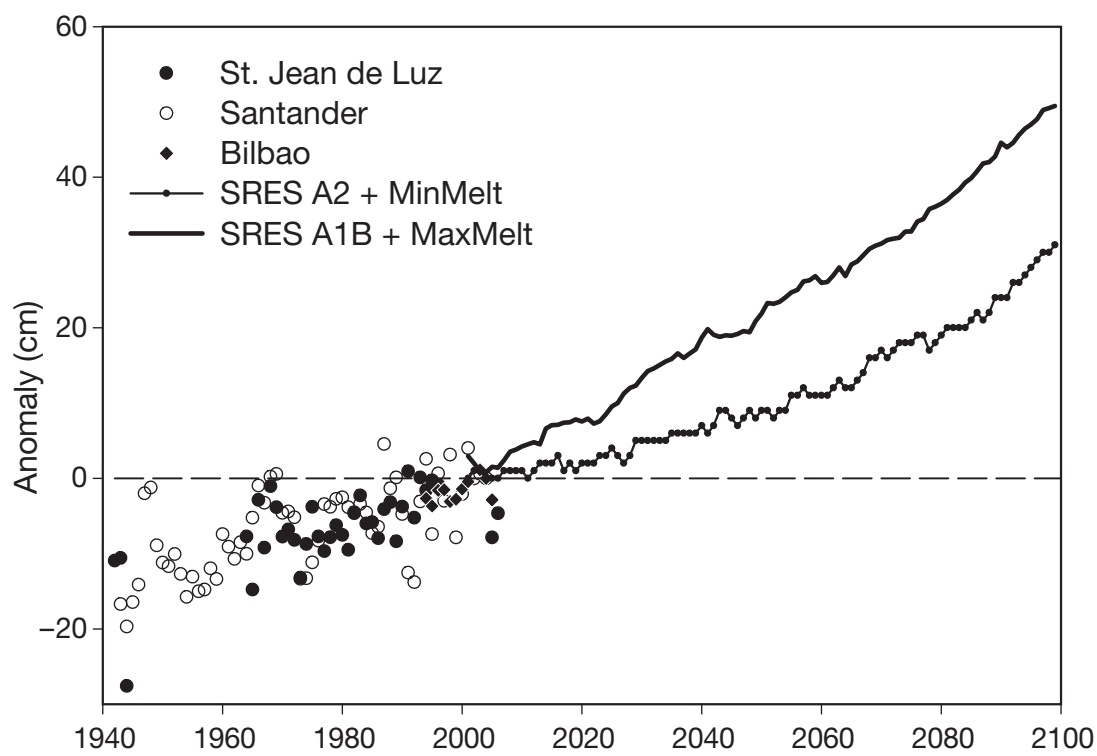

Fig. 5. Observed annual mean sea level series (large circles and diamonds) for the tide gauges of Santander, St. Jean de Luz and Bilbao, and projected levels (lines) for the 21st century under 2 Intergovernmental Panel on Climate Change (IPCC) climate scenarios. Mean sea levels are given as anomalies with respect to the level at Santander in 2004. Expected global sea level rise from the melting of ice sheets and glaciers is between $4 \mathrm{~cm}$ (MinMelt) and $20 \mathrm{~cm}$ (MaxMelt) by the end of the 21st century (Meehl et al. 2007). The mean sea level of all data sets is with reference to the level in 2004. Modified from Chust et al. $(2009,2010)$ 


\subsubsection{Projections for the 21 st century}

In the Bay of Biscay, Chust et al. (2010) computed thermosteric sea level variations for the 21st century from temperature outputs of the AOGCM projections within the area for 2 climate scenarios. Salinity changes were excluded in that study since the averaged salinity over the upper $100 \mathrm{~m}$ of the water column is not expected to change throughout the 21st century. The results of the study have shown that from 2001-2099, the SLR within the Bay of Biscay is estimated at between 28.5 and $48.7 \mathrm{~cm}$ (Fig. 5), as a result of regional thermal expansion and global ice melting $(4-20 \mathrm{~cm})$, under scenarios A1B and A2 of the IPCC AR4. These regionally projected SLRs are similar to global estimates under the same scenarios (A1B: 21$48 \mathrm{~cm}, \mathrm{~A} 2:$ 23-51 cm; Meehl et al. 2007). However, the accelerated decline of polar ice sheet mass indicates that global SLR could be significantly larger (Nicholls \& Cazenave 2010) than those projected by the IPCC AR4, with estimated rises of $0.8 \mathrm{~m}$ (Pfeffer et al. 2008) and 0.5 to $1.4 \mathrm{~m}$ (Rahmstorf 2007).

\subsection{Hydroclimatic variability and anomaly patterns: observations in the 20th century}

The annual cycle of the shelf waters within the southeastern Bay of Biscay is characterised by changes in the relative prevalence of downwelling and upwelling mechanisms (Valencia et al. 2004). Hence, within this area and during the period 1958-1976, there was weak mean annual downwelling $\left(-200 \mathrm{~m}^{3}\right.$ $\left.\mathrm{s}^{-1} \mathrm{~km}^{-1}\right)$, or even low upwelling $\left(130 \mathrm{~m}^{3} \mathrm{~s}^{-1} \mathrm{~km}^{-1}\right.$; Fig. 6). However, after 1977, the mean annual downwelling values were established at around $-300 \mathrm{~m}^{3} \mathrm{~s}^{-1}$ $\mathrm{km}^{-1}$, with the lowest values (-500 to -600$)$ occurring within the period 1998-2002. These high downwelling value periods coincide with high turbulence $\left(>400 \mathrm{~m}^{3}\right.$ $\mathrm{s}^{-3}$ ). After 2003, there is less downwelling and a decrease in turbulence (Fig. 6).

The relief of the southeastern part of the Bay of Biscay results in a strong continental influence over the Basque coast. Comparatively, the southern Bay of Biscay has marked thermal zoning, from a cold southwestern part (Galicia) where the oceanic influence is greater, towards the inner part where continental influence is stronger. The intensity and frequency of upwelling events decreases southeastward as temperature and stratifi- cation increase (Valencia et al. 2004). On a seasonal basis, the cycle in SST varies from the southwest towards the southeast (Lavín et al. 2006). In Galicia, the temperature range from summer to winter is reduced more, as upwelling cools the water in summer. In the southeastern part of the bay, in contrast, there is more influence from the land climate and the shelf waters are less saline, colder in winter, and warmer in summer (Valencia et al. 2003, 2004, Alvarez et al. 2010).

In terms of atmosphere-ocean interaction, coupling mechanisms between climate and water mass properties and circulation have been documented for the region (Pérez et al. 2000, García-Soto et al. 2002, Pingree 2005). Although the NAO greatly influences the circulation in the north Atlantic, its influence is less significant in the northeastern Atlantic, especially in the intergyre zone and the inner Bay of Biscay (Trigo et al. 2002). The most influential atmospheric pattern seems to be the East Atlantic (EA) pattern, particularly for the southeastern Bay of Biscay, by means of the influence of a low pressure centre to the west of the British Isles. Several studies have demonstrated that over the area adjacent to the Bay of Biscay, the EA pattern is related to (inter alia) the variability of precipitation related the position of the Atlantic storm track (Rogers 1997), winter land temperature through heat fluxes (Sáenz et al. 2001b), anchovy recruitment (Borja et al. 2008), autumn-winter temperature, evaporation and moisture transport (Valencia et al. 2009), and upwelling patterns (Borja et al. 2008, Alvarez et al. 2010). Hence, the positive phase of the EA index after 1997 can explain the trend in the upwelling-downwelling pattern in the southeastern Bay of Biscay (Borja et al. 2008).

In terms of atmosphere-sea interaction, significant coupling between oceanographic and meteorological data is observed for the southeastern part of the Bay of Biscay, showing that the atmospheric temperature

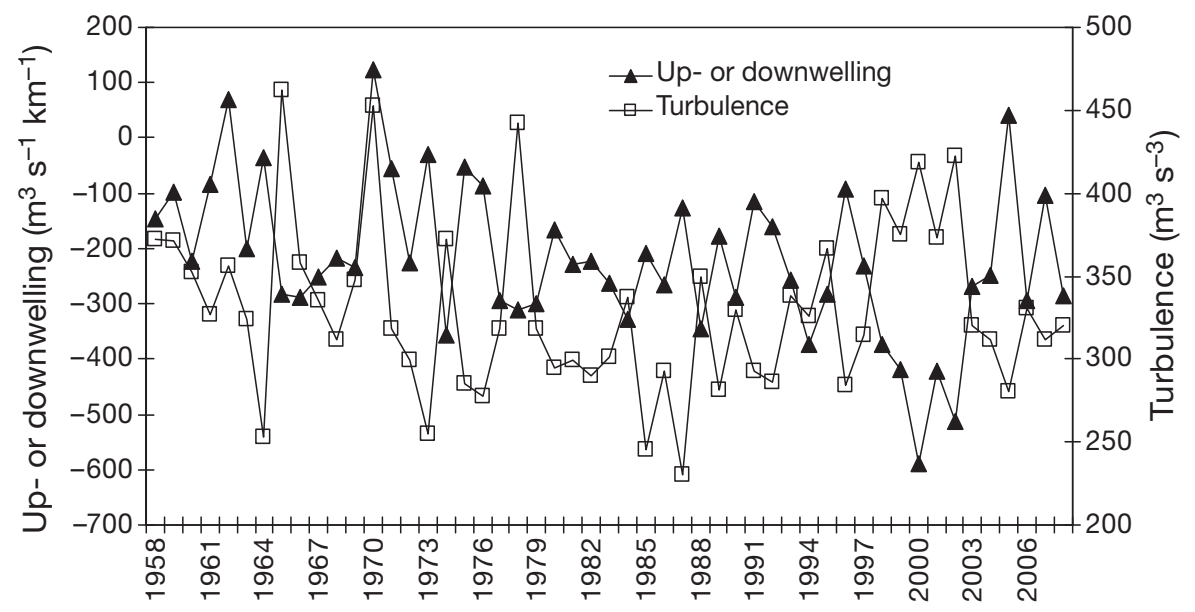

Fig. 6. Up- and downwelling and turbulence annual mean time series for the southeast area of the Bay of Biscay (data updated from Valencia et al. 2004) 
significantly influences the variability in SST and, to a lesser degree, the thermal bulk of the water column (Fontán et al. 2008, Goikoetxea et al. 2009).

Within the last decade, frequent seasonal anomaly patterns of oceano-meteorological variables have been observed in the southeastern Bay of Biscay (Fontán et al. 2008, Goikoetxea et al. 2009). These authors concluded that the duality of cold winters and long warm summers prevails in comparison with the seasonal cycle of the temperate Atlantic areas. Moreover, the period 2003-2005 was characterised by the prevalence of warm spring and summer seasons, with cold autumn and winter periods. Exceptional events such as those during the last decade (González-Pola et al. 2005, Somavilla et al. 2009) are explained not only by air temperature fluctuations, but also by other meteorological and physical parameters such as irradiance, turbulence and upwelling events (Borja et al. 2000, Goikoetxea et al. 2009).

In addition to the thermal anomaly patterns, other variables also indicate shifts with respect to the average seasonal patterns. For instance, although the Basque coast is characterised by downwelling conditions in autumn, upwelling conditions prevailed in the autumn of 2005. Similar results were obtained by Borja et al. (2008) and deCastro et al. (2008a,b), who noted that the positive phase of the EA was directly related to ufavourable upwelling conditions along the eastern (Borja et al. 2008) and northwestern (deCastro et al. 2008) coasts of the Bay of Biscay.

Although frequent seasonal anomalies are evident, few anomalies in terms of annual average values can be identified (Fontán et al. 2008). Hence, despite several regime shifts and anomaly patterns for different ocean-meteorological indices (e.g. ENSO, NAO, EA) throughout the last decades, only limited consolidated trends can be reported for the southeastern Bay of Biscay; this is probably related to the counteracting effect of some extreme conditions, i.e. the very warm summer in 2003 compared to the very cold winter in 2005 (González-Pola et al. 2005, Fontán et al. 2008, Somavilla et al. 2009). Although the observed rise in SST can result in an increase in thermal stratification, the storm events and wave climate prevailing during recent decades have produced turbulent mixing and thermal homogeneity.

\subsection{Wave climate}

\subsubsection{Observations in the 20th century}

Waves are generated directly by wind forcing; as such, global climate change can affect regional wave climates. In the North Atlantic, for example, the inter- annual evolution of wave heights is related, at least partially, to climatic factors, such as the NAO index (The WASA Group 1998, Wolf \& Woolf 2005). Woolf et al. (2003) found that most of the interannual variability of winter wave climate around the British Isles can be related to the NAO. According to Lionello \& Galati (2008), the EA pattern (Wallace \& Gutzler 1981) has a greater influence on the variability of waves than the NAO over the western Mediterranean. Dupuis et al. (2006) reported that the wave height recorded at a station located in the southern Bay of Biscay (Biscarosse) did not show any significant correlation with the NAO, whilst wave periods were positively correlated.

Several studies have investigated the evolution of wave climate in the northern part of the North Atlantic Ocean (e.g. Grevemeyer et al. 2000). Most of these studies, based on observations, indicated a general upward trend in wave heights (e.g. Dupuis et al. 2006, Debernard \& Røed 2008). In contrast, numerical models based upon reanalysis (The WASA Group 1998), have suggested that wave height over most of the northeast Atlantic and in the North Sea has decreased from 1955-1994. However, the present intensity of storms and wave climate seems to be similar to that observed over the last 100 yr (The WASA Group 1998).

The analysis of the period 1980-1998 within the eastern Bay of Biscay (off Biscarosse, France) has shown that wave heights tend to decrease (Dupuis et al. 2006). In turn, an analysis of the longest time series $(40 \mathrm{yr})$ for the area, on storm surges and wave heights in Santander, has suggested that these extreme events have intensified over the last decade (F. Méndez pers. comm.).

\subsubsection{Projections for the 21 st century}

Empirical projection models for the Cantabrian coast indicate that wave heights (both the mean regime and extreme events) will increase by 2050 (Ministerio de Medio Ambiente 2006). In particular, significant wave heights exceeding $12 \mathrm{~h} \mathrm{yr}^{-1}\left(\mathrm{H}_{\mathrm{s} 12}\right)$ are expected to increase from 0.26 to $0.30 \mathrm{~cm} \mathrm{yr}^{-1}$ along the Basque coast. Extreme events with wave heights $\mathrm{H}_{\mathrm{ST} 50}$ (significant wave heights with a 50 yr return period) will increase only slightly. The prevailing direction of the waves is also expected to change and to be more westerly. The potential intensification of storms will affect Basque coastal areas that are more exposed to the prevailing wind and wave directions (NW) (González et al. 2004), i.e. the east part of Gipuzkoa and the western part of Bizkaia. Although these new wave climate regimes may affect the morphology of the coasts, the reliability of these projections is still uncertain (Cendrero et al. 2005). 


\section{IMPACTS ON COASTAL AREAS AND BIODIVERSITY}

\subsection{Coastal flooding}

SLR and the intensification of extreme wave climate events during the 21st century are considered to be among the major threats to coastal ecosystems (Nicholls et al. 2007, FitzGerald et al. 2008, Defeo et al. 2009). An increase in mean sea level induces a higher risk of the flooding of low-lying coastal areas, erosion of sandy beaches and barrier island coasts, intrusion of saltwater and the loss of wetlands, amongst other effects (Wolanski \& Chappell 1996, Morris et al. 2002, Crooks 2004, Pascual \& Rodríguez-Lázaro 2006, FitzGerald et al. 2008, Kirwan \& Murray 2008a, Kirwan et al. 2008, Poulter \& Halpin 2008, Gesch 2009). These climate-change-driven threats will probably exacerbate several existing pressures along the coastal regions such as the concentration of population (McGranahan et al. 2007) and the increasing rate of urbanisation (European Environment Agency 2006), causing degradation, fragmentation and habitat loss (Fahrig 2003, Halpern et al. 2008).

Evidence of the impacts of SLR throughout the 20th century is relatively scarce (Williams et al. 1999, 2003, Denslow \& Battaglia 2002, Jokiel \& Brown 2004, De Santis et al. 2007), compared with the future threats expected for the next $100 \mathrm{yr}$ (see reviews by Nicholls et al. 2007 and FitzGerald et al. 2008). To establish clear evidence of SLR effects at the habitat level is difficult in most cases because of the overwhelming anthropogenic changes, and because of the difficulty of differentiating between natural processes (such as wave action) and the effect of SLR on the beach retreat (FitzGerald et al. 2008). For instance, a loss of 3 ha of sandy beaches and saltmarshes within the eastern Basque coast has been detected using historical data and attributed to $10 \mathrm{~cm}$ SLR from 1954-2004, whilst the simulated effect was 11 ha over the $50 \mathrm{yr}$ period (Chust et al. 2009).

Concerning future threats, efforts have been concentrated upon large low-lying areas and deltas (e.g. Ericson et al. 2006, McGranahan et al. 2007). However, on steep coasts, such as the Basque and the remainder of the Cantabrian coast, the sea cliffs and hilly relief limit the extent of the sandy beaches, saltmarshes, urban settlements and indus- trial zones along the coast. Therefore, these confined habitats and infrastructures are vulnerable to small variations in sea level and wave climate (Michael 2007, Vinchon et al. 2009). Within this context, Chust et al. (2010) used a high-resolution digital terrain model to assess the potential impact of the estimated SLR by 2099 (49 cm, see section 2.4.) on natural and artificial coastal habitats in this area. Similar approaches were applied previously by Webster et al. $(2004,2006)$ along the coast of New Brunswick (Canada). The flood risk map generated for the Gipuzkoa coast indicates that 111 ha of the supralittoral area may be affected by the end of the 21st century (Fig. 7). Whilst the effects of SLR are concentrated in low-lying areas within the inner estuaries, extreme waves predicted with a $50 \mathrm{yr}$ return period will affect mainly sandy beaches, harbours and urban areas exposed to high energy waves (author's unpubl. data, see Fig. 7).

The regime of flood events in the Basque Country will change also due to the expected decrease in mean precipitation and the increase of extreme rainfall for the 21st century (see section 2.2.). The rivers draining to the Basque coast are torrential in character, with very short time lags between the precipitation and resulting river discharge. Thus, lower river flow and higher intensity floods are expected, as well as changes in the water properties of the estuarine waters. Since the major concentrations of suspended matter take

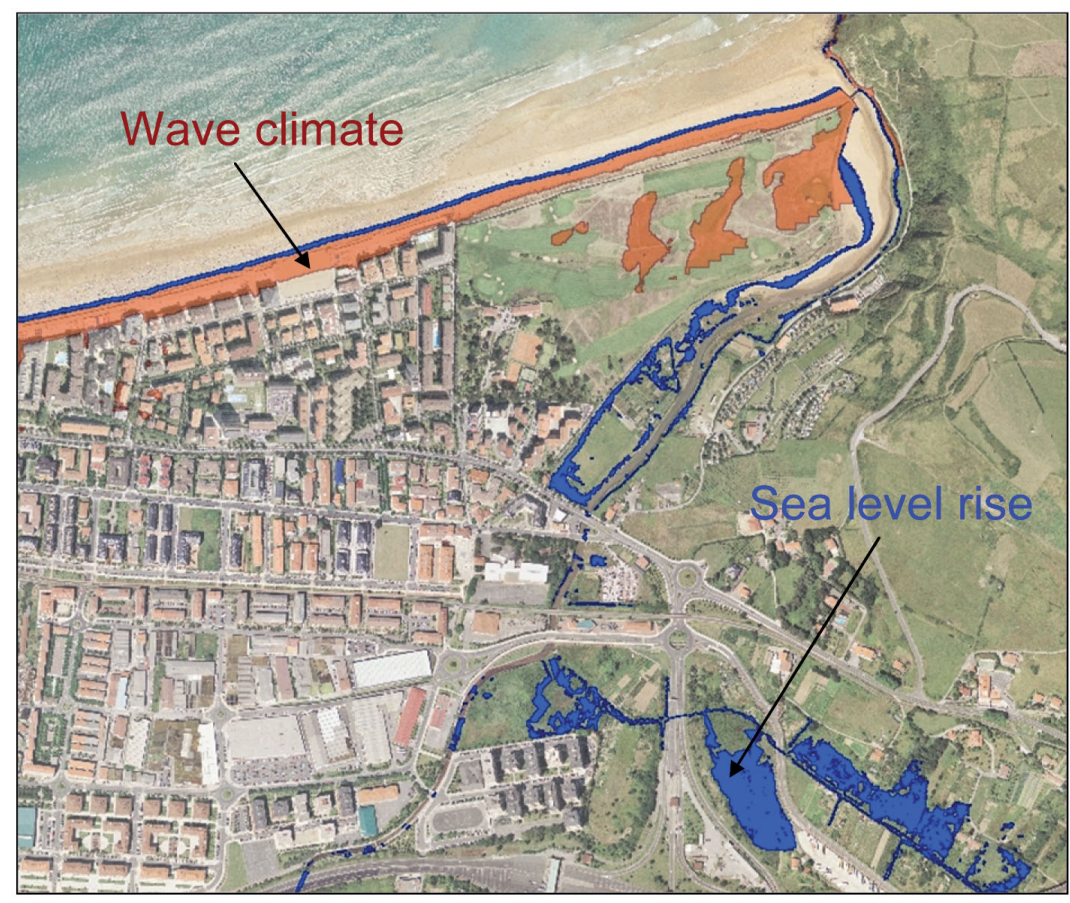

Fig. 7. Flood-risk map expected for a $49 \mathrm{~cm}$ sea level rise in 2100 (blue) and extreme wave climate for a 50 yr return period (orange), in Zarautz (Basque coast, Spain; authors' unpubl. data) 
place during intense rainfall, following dry periods (Uriarte et al. 2004), the new expected precipitation regime will induce intensification of these conditions. As a consequence, the estuarine ecosystems will be subjected to more contrasting periods of lower river flow waters to higher hydrodynamic, turbid waters. If these expected rainfall regimes and temperature increases also take place in adjacent areas, nearby rivers such as the Adour (France), which can affect the Basque coastal waters during large freshwater discharges (Ferrer et al. 2009, Petus et al. 2010), could shift from a nival regime to a nival-pluvial regime.

\subsection{Retreat of sandy beaches and dunes}

A direct consequence of SLR is the displacement of the high-water mark landward, causing beaches to migrate slowly inland (Defeo et al. 2009), together with the permanent or long-term loss of sand from the beaches (FitzGerald et al. 2008). Low-gradient dissipative shores are most at risk, compared with steep coarse-grained beaches; this is due to their erosive nature and the much greater run-up of swashes on gentle gradients (Defeo et al. 2009). Confinement of the sand beaches through the construction of coastal structures also makes them more prone to erosion (FitzGerald et al. 2008). Because the effects of global SLR on coasts will vary spatially and at the habitat level, the prediction of coastal changes should be approached on regional to local scales and be map based. Studies undertaken in Aquitaine (France), for example, indicate that climate change will induce a significant increase of erosion hazard for most of the sandy coast (Vinchon et al. 2009); on the cliff-lined coast, small and narrow beaches are likely to retreat drastically, if not disappear altogether, because of limited sediment storage.

Along the Basque coast, 2 approaches were adopted to assess the beach erosion expected by an SLR of $49 \mathrm{~cm}$ in Chust et al. (2010). The first approach, based on geographic information system (GIS) analysis, evaluates the retreat of beach habitats using extensive high-resolution height data. In particular, the area between the coastline defined by the maximum high tide and the coastline generated by adding the estimated future SLR was delimited using GIS. The second approach took into account the redistribution of sediment along the sandy beaches, according to the Bruun Rule, i.e. the 'equilibrium profile' (Bruun 1988, FitzGerald et al. 2008), of each beach analysed, from a set of 15 main beaches selected. Although criticisms and modifications to the Bruun Rule have been suggested (Cooper \& Pilkey 2004, Davidson-Arnott 2005), it serves as an indication of how the flood-risk map is biased in relation to accounting for movements of material in response to the SLR. According to the study, sandy beaches on the Basque coast are expected to suffer shoreline retreats of between $25 \%$ of the average beach width (GIS-based approach) and $40 \%$ (Bruun approach). In both the map-based and the Bruun approaches, the number of beaches in which the supralittoral zone is expected to disappear is lower ( 2 to 3 of the 15 analysed beaches) than the previous estimates given by Cendrero et al. (2005), i.e. 12 out of 19 beaches. Cendrero et al. (2005) applied the Bruun Rule on a single beach profile assuming erosion of $1 \mathrm{~m}$ for every $1 \mathrm{~cm}$ of SLR. On the other hand, 17 out of the 19 beaches of Gipuzkoa are already at present naturally or artificially confined (Chust et al. 2009); this makes them more likely to disappear (FitzGerald et al. 2008). As a consequence of the migration of the entire beach profile landward under the SLR scenario, some vegetated dune patches may disappear because of the presence of the artificial rigid seafronts.

The new estimates of beach retreat may have impacts on different goods and services that sandy shores provide, such as biodiversity and recreational activities. Coastal vegetated dunes, especially grey dunes, hold highly specialised floristic diversity and are included as priority habitat in the Natura 2000 network (Habitats Directive 1992). Although the threat to dune habitat is less than for the supralittoral sandy beaches, historical loss, degradation and squeezing by urbanisation makes them more vulnerable. In terms of services, tourism is an important sector in the Basque Country, contributing from 4.7 to $5.3 \%$ of the gross domestic product (from 2000 to 2004, www.eustat.es). The success of this industry depends, at least partially, on the quality of the sandy beaches and the ebb tidal deltas (Liria et al. 2009). Within a scenario of beach retreat, either tourism may decline, or alternatively the pressure of recreational seashore activities will overwhelm the sandy beaches.

The joint effect of accelerating SLR and ongoing coastal urbanisation processes in the area (Chust et al. 2007) is of particular concern for beach erosion, especially for vegetated dunes (Defeo et al. 2009) and within the context of higher global SLR projections by 2100 , which were recently reported to be between 0.5 and $1.4 \mathrm{~m}$ (Rahmstorf 2007, Pfeffer et al. 2008). Sandy beaches are identified as one of the most threatened coastal habitats of the Basque coast. Adaptation strategies to face SLR-induced beach erosion should include measures to promote coastal resilience, including protection, stabilisation and regeneration of dune plants, the maintenance of sediment supply, and the provision of buffer zones by providing setback zones which would allow the beach to migrate landward (Defeo et al. 2009). 


\subsection{Estuaries, saltmarshes and wetlands}

\subsubsection{Relationship between climate and estuarine species}

Long-term series of estuarine biological data from the Basque Country are scarce, starting in 1989 for the Nervión and Barbadún estuaries (see Fig. 1b for locations) (Borja et al. 2006) and in 1995 for the remainder (Borja et al. 2004b). Using these data, Pérez et al. (2009) studied the temporal trends in Basque estuarine soft-bottom macrofaunal communities, explained by anthropogenic, climatic and sedimentological factors. As these estuaries have been polluted historically (Cearreta et al. 2004), this has affected of benthic communities in recent years (Borja et al. 2009). Overall, sediments are the most relevant factor, explaining $17.2 \%$ of benthic variability in the species density, whilst anthropogenic variables (pollutants) explain $16.9 \%$ and climatic variables represent only $15.4 \%$ of the variability (Fig. 8). Hence, substratum and pollution explain most of the variability of these altered systems, with climate factors being less relevant for the Basque benthic estuarine communities.

On the other hand, in the case of plankton communities, climatic variables seem to play an important role, even in historically-polluted estuaries, such as that of Nervión. Hence, Villate et al. (2008) described for the Oka estuary a chain of effects from the NAO to chlorophyll: air temperature inversely followed the NAO index, water temperature followed air temperature, and chlorophyll a (chl a) followed water temperature. Aravena et al. (2009a) described similar relationships in both the Oka and Nervión estuaries, including river

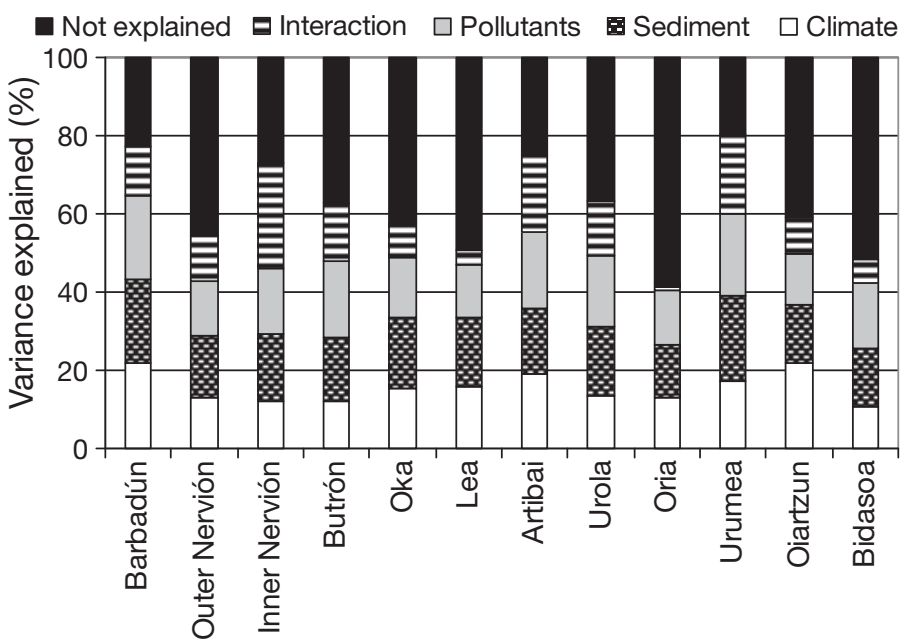

Fig. 8. Partition of the variance explained by different natural (climate, sediment) and anthropogenic (pollutants) factors, together with the interactions of those factors, in soft-bottom benthic communities in Basque estuaries (data from Pérez et al. 2009) discharge and rainfall. Related to zooplankton, Aravena et al. (2009b) recorded several species of Acartia copepods in the Nervión estuary between 1998 and 2005. A. clausi dominated the euhaline stretch of the estuary until 2003, when it was displaced from the inner part by $A$. tonsa, due to environmental changes. The decrease in A. clausi abundance in low-salinity waters was related to a significant decrease of dissolved oxygen saturation levels, whereas the increase in temperature was linked to a significant increase of A. tonsa. A. margalefi and A. discaudata were scarce over the entire period, but they were valuable indicators of hydrological changes associated with climate factors.

\subsubsection{Sea level rise and estuarine habitats}

The impacts of SLR in estuaries could lead to changes in the extent of the low-lying areas, the migration of saltmarshes landward, salinisation of aquifers and changes in sediment and nutrient transport (Crooks 2004, FitzGerald et al. 2008). Elevation relative to mean sea level is a critical variable for the establishment and maintenance of biotic coastal communities and a threat to biodiversity (Kirwan \& Murray 2008b, Kirwan et al. 2008), as has been detected in the past for the Basque Country (Pascual \& Rodríguez-Lázaro 2006). In tidal areas, this elevation determines the duration and frequency at which coastal habitats are submerged, this being one of the factors controlling the productivity of macrophyte communities (Morris et al. 2002). The SLR is already causing the retreat of coastal forests (Williams et al. 1999, 2003, DeSantis et al. 2007), the loss of saltmarshes (Denslow \& Battaglia 2002, Chust et al. 2009), coral reef bleaching (Jokiel \& Brown 2004) and the loss of goods and services (Costanza et al. 1997, Schröter et al. 2005, Michael 2007).

Along the Basque coast, a study of the impacts of $49 \mathrm{~cm}$ in SLR on the Gipuzkoa estuaries was undertaken by Chust et al. (2010). This study revealed that 3.9 ha of wetlands and saltmarshes (i.e. $6.5 \%$ of the surface) may be affected (Fig. 7). The impact assessment of such an approach is useful in assessing relatively large areas at high resolution and is reliable for hard substrata. However, marshes are dynamic systems which respond to SLR according to a balance between accretion and subsidence, bioproductivity and decomposition, erosion and vegetative stabilisation, and tidal prism and drainage efficiency (Morris et al. 2002, FitzGerald et al. 2008, Reeve \& Karunarathna 2009). In essence, the vertical accretion, as defined as net vertical growth of the marsh, results from both mineral sediment influx and the production of organic 


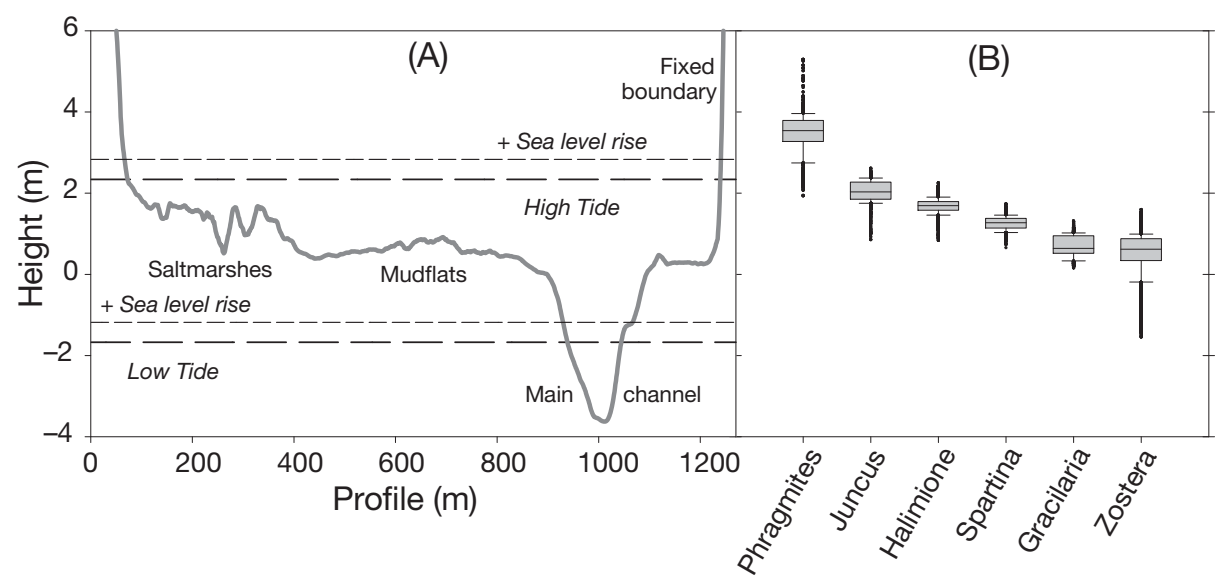

Fig. 9. (A) Height profile derived from bathymetric data of intertidal habitats in the inner Oka estuary (Basque coast). High tide and low tide are the observed mean spring tide values for the Bilbao I tide gauge station. (B) Height distribution of main intertidal flora of the innermost Oka estuary (Phragmites australis, Juncus maritimus, salt marshes dominated by Halimione portulacoides and Salicornia sp., Spartina maritima, Gracilaria sp., Zostera noltii). Plots show the median, 10th, 25th, 75th and 90th percentiles as vertical boxes with error bars, and outliers (crosses). Height data were extracted from bathymetric LiDAR system acquired in June 2007

matter; this, in turn, determines the future evolution of the marsh in response to SLR (Morris et al. 2002). Saltmarshes are capable of being near equilibrium in relation to rates of SLR (Friedrichs \& Perry 2001), whilst under specific conditions, they could lag by several decades (Kirwan \& Murray 2008b). An average accretion rate of $3.7 \mathrm{~mm} \mathrm{yr}^{-1}$, as calculated for the Basque marshes in the 20th century by Leorri et al. (2008), suggests that these marshes are potentially able to adjust to the projected SLR rates.

On the other hand, when the accretion is below the rate of SLR, which can take place within mudflats, the habitat suitable for vegetation can be reduced in some cases-e.g. where the coastal margin is squeezed between the fixed landward boundary (artificial or natural) and the SLR, i.e. the so-called 'coastal squeeze' effect (Schleupner 2008). To test the case of a natural fixed boundary, a species-specific habitat model was developed for the intertidal seagrass Zostera noltii in the Oka estuary (Basque coast, see Fig. 1b), using ecological niche factor analysis (Valle et al. 2010). The dependence of this seagrass on the inundation frequency of tides (Fig. 9), together with a highresolution bathymetry generated by an airborne LiDAR system, enabled these authors to map the present habitat suitability and estimate the future scenarios. The area of suitable habitat (with a probability of presence $>50 \%$ ) for $Z$. noltii in the Oka estuary is expected to be reduced by $40 \%$ by the end of the 21st century, as a con- sequence of the future SLR (author's unpubl. data, Fig. 10). This result suggests that migration of the seagrass landward, following the SLR, can be limited by the estuarine profile (Fig. 9). The habitat distribution of this seagrass also depends upon the hydrodynamic conditions and grain size features. Thus, ongoing research in numerical modelling on future sediment redistribution should enhance the reliability of habitat loss estimates.

The projected rise in air temperature in the Basque Country (section 2.1) and sea temperatures within the Bay of Biscay (section 2.3) might also interact negatively with SLR, having implications in terms of the loss of coastline biodiversity. On the one hand, the warming of marine waters may cause the migration of
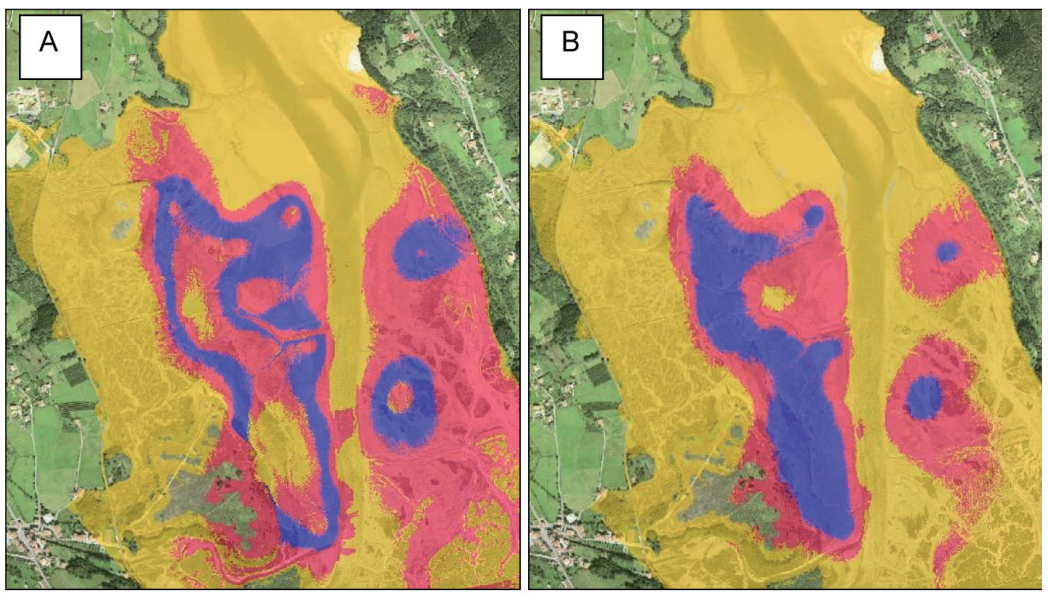

Fig. 10. Habitat suitability for Zostera noltii in the Oka estuary (Basque coast) (A) at present (2008) and (B) expected by the end of the 21st century as a consequence of future sea level rise. Habitat suitability is classified into 3 probability ranges of occurrence: 0 to $33 \%$ (yellow), 34 to $66 \%$ (red) and 67 to $100 \%$ (blue) (authors' unpubl. data) 
intertidal species with a narrow niche to higher latitudes. On the other hand, the eventual loss of small saltmarshes leads to fragmentation of the estuarine habitat patches along the coast, thereby reducing the potential connectivity between local populations (Fahrig 2003). Thus, similar to the contraction of alpine species distribution, estuarine species populations with narrow niches, with limited dispersal potential (Defeo et al. 2009) and with fragmented habitat by historical urbanisation in a particular area, may be at local extinction risk under climate change.

Wetlands and marshes in the Basque estuaries are also squeezed by croplands and pastures that lie within the original

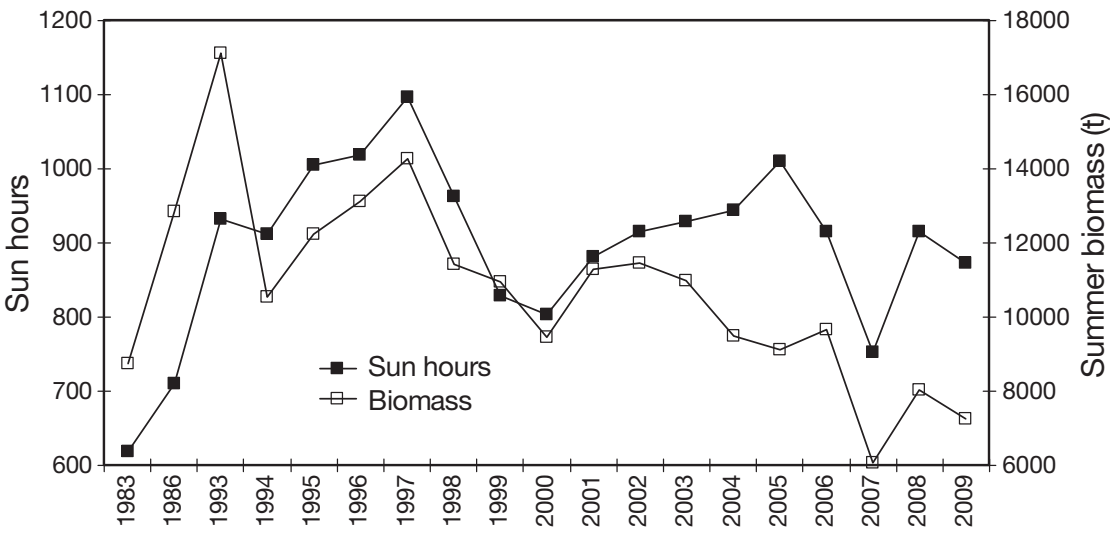

Fig. 11. Gelidium corneum. Evolution of biomass between Orio and Hondarribia in summer, and sunlight hours in winter-spring (January-June), for the period 1983-2009 (updated data from Borja et al. 2004a)

with low levels of irradiance, but also with a high number of waves $>6 \mathrm{~m}$ in significant height, which can be considered as being able to detach algae from the bottom (Borja 1994). Hence, from 2002-2006, for the period of January-June, the number of cases in which waves were $>6 \mathrm{~m}$ ranged between 0 and 6 , whereas they ranged between 10 and 14 for the period 20072009. Some of the last cases were in April-June, close to the biomass assessment period, at the end of June (authors' unpubl. data). This factor produces an early detachment of algae, and, together with a low level of production due to low irradiance, results in a low summer biomass.

In other subtidal macroalgae species, such as Saccorhiza polyschides, temperature appears to be the most important factor in their distribution along the Basque coast throughout the 20th century (Borja \& Gorostiaga 1990). S. polyschides, a cold-water species, decreased in abundance and retreated in its range along the Basque coast during periods of warming (i.e. 1950s); the reverse occurred during periods of cooling (e.g. 1970s). This is probably why this species has disappeared from the Basque coast since the end of the 1990 s and in the 2000s, coinciding with the warmest period since 1946 (section 2.3.). Similar patterns of expansion and retreat have been detected in intertidal hard-bottom fauna and flora (e.g. limpets, barnacles, Littorina, Laminaria, Fucus, Bifurcaria) throughout the Bay of Biscay through the 20th century (Southward et al. 1995, 2004, Alcock 2003).

In the case of soft-bottom benthic communities, the dataset commenced in 1995 (Borja et al. 2004b). Using this information (19 subtidal coastal stations, $12 \mathrm{yr}$, and 275 species), Garmendia et al. (2008) showed that sediment variables explained $11.1 \%$ of the total community inertia, whereas anthropogenic variables (pollutants) explained only $4.8 \%$ of the variability. Climatic variables were the most important, explaining 
$17 \%$ of the total variability. Of the latter, the most important variables were river flow (explaining 49.2\% of the variability), precipitation $(7.3 \%)$, winter NAO $(6.9 \%)$, sunshine $(6.6 \%)$ and EA (5.9\%). Hence, it seems that although in Basque estuaries, sedimentological and anthropogenic factors determine benthic abundance (see above), in coastal waters climatic variables generally explain most of the variability of such abundance. Only in areas more affected by pollution (e.g. near wastewater discharges), are anthropogenic factors determining the evolution of benthic abundance.

\subsubsection{Predictions in benthos changes}

Investigations into the prediction of the effects of climate change on coastal benthos, within the Bay of Biscay, are concentrated within the northern part of the bay (Southward et al. 1995, 2005). Southward et al. (1995) predicted a general shift of warm water species to the north, together with a retreat of the cold water species. Additionally, they predicted the definitive decline in some species, such as the native oyster Ostrea edulis, which is already under threat from pollution and introduced pathogens, and will likely be replaced by warmer water species from the genus Crassostrea, as has already been detected in the Basque Country.

Using a graphical model (with the summer and winter limits of temperature for benthic species), Alcock (2003) predicted changes in 18 intertidal species until 2050. In general, for those warm water species (e.g. Patella rustica, Pollicipes pollicipes) with a present geographical limit on the Basque or French coasts, expansion to the north of the British Isles and to the south of the North Sea is predicted. Species presently extending to the south of the British Isles (e.g. Osilinus lineatus, Gibbula umbilicalis, Balanus perforatus, Patella depressa) will expand to southern Norway. In turn, cold water species (e.g. Patella vulgata, Nucella lapillus, Semibalanus balanoides, Pelvetia canaliculata, Fucus vesiculosus, F. serratus, Laminaria hyperborea), which are present only in the western and northern parts of the Bay of Biscay, will disappear completely from the bay by 2025. In some cases, such as N. lapillus, this has already been detected. This species was identified in the 1980s off the Barbadun estuary (Borja et al. 1982), and began disappearing from the Basque coast in the 1990s, with the increase in sea temperature.

On the other hand, using robust supervised classification methods, as applied to fish recruitment (Fernandes et al. 2010), prediction of the summer Gelidium corneum biomass was attempted, taking into account sun hours, waves, winds, NAO and EA. Data from 1993-2009 showed that EA and sun hours are the factors which best explain the variability in the summer biomass. Hence, scenarios considering low sun hours $(<929)$ in winter and spring, together with mean EA values ( 0 to 0.7 ), predicted $80 \%$ of probability of having low Gelidium biomass ( $<7000$ t) and $20 \%$ of probability of moderate biomass (7000-8000 t).

\subsection{Urban coastal environment}

The main climate drivers that could affect urban environments are the increase (decrease) of heat (cold) stress in summer (winter), a change in precipitation patterns, SLR and increasing extreme weather events, such as storms and flooding (Wilbanks et al. 2007). The impacts of global climate change on urban environments depend markedly on the geographical location and the industrial development of human settlements. In Europe, the main climate drivers that could affect coastal urban environments are wind-driven waves and storms, together with the SLR (Alcamo et al. 2007). The main impacts of these drivers on urban areas are flooding, coastal defence failures and the damaging of infrastructures; likewise, rising water tables could impede the drainage and cause salinisation of groundwater (Nicholls et al. 2007, Devoy 2008).

Along the Basque coast, urban areas are located mostly within the estuaries; of the $45 \%$ of the estuarine areas lost following the post-Flandrian retreat, 90\% was due to land reclamation (Rivas \& Cendrero 1994). The purposes of the landfill of estuarine areas, which began in the 17 th century, were socioeconomic, viz. agriculture, industrial installations, residential areas and transport infrastructure, amongst others (Díez et al. 2000). Although the coastal municipalities occupy $14.6 \%$ of the total surface of the Basque Country, $60.4 \%$ of the total housing is concentrated within such areas. The population density at the coast is 4 times higher than that of the Basque Country as a whole. With regard to the infrastructure, there are 17 ports, an airport, several roads and rail links and around 30 sewage treatment plant within this region. Thus, climate drivers, mainly the frequency of the storms and the SLR (Cendrero et al. 2005), could affect the socioeconomic activities of the Basque coast.

Assuming a scenario of $49 \mathrm{~cm}$ in SLR for 2099 (section 2.4.), the artificial area in the Gipuzkoan coast that could be flooded is 35.2 ha (Chust et al. 2010). A greater part of these areas are those which have been reclaimed since the 17 th century, including industrial, residential, harbour and transport infrastructure, such as roads and an airport. Their vulnerability will be higher at high tides and during sea storms (Fig. 7). Amongst the affected areas, those located within estuaries will be even more vulnerable, since besides SLR and high tides, they will also be exposed to river floods. 
At present, the predicted flooded areas are protected by defences against flooding; these will not be overtopped with the projected SLR, providing that the defences do not fail. Nevertheless, the flood defences will support a higher water volume and consequently may suffer more erosion.

Harbour infrastructures and external dykes are also thought to be affected by climate change. The combined action of sea level and wave height rise will increase the overtopping of the piers located along the Cantabrian coast; in some cases their stability will diminish. Assuming a standard dyke, the overtopping (water volume exceeding the height of the dyke above sea level) over the main external dykes of the Basque coast will increase by at least $30 \%$ from the beginning to the end of the 21st century (authors' unpubl. data). This result was obtained under a scenario of sea level and significant wave height (exceeding $12 \mathrm{~h} \mathrm{yr}^{-1}$ ) rise. In the case of the main harbours of the Basque coast, the sole impact of SLR will imply a smaller distance between the levels of the highest astronomical tide and that of their piers, towards the end of the 21st century (Chust et al. 2010); in time, this may diminish the functionality of the piers. If the geometry of the navigation channel is modified, this could also affect navigation into the harbours (Acinas 2002). The rising seawater tables would also increase salt water intrusion; hence, it could threaten drainage systems and the groundwater such as those of Gernika, which are occasionally contaminated by salt water (B. G. Bikuña, M. Moso, J. Arrate, S. Lujan unpubl. data).

\section{IMPACTS ON THE PELAGIC ENVIRONMENT}

\subsection{Chlorophyll and primary production}

\subsubsection{Long-term trends}

Most of the time-series measurements of phytoplankton in the Bay of Biscay are coastal or estuarine. Furthermore, all of them cover $<25 \mathrm{yr}$, which makes it difficult to extract long-term trends. The results from coastal time series differ locally. Off Gijon, a decrease in primary production has been observed over the last 10 yr (Valdés et al. 2007, Llope et al. 2007), whereas an increase has been observed off La Coruña, around the area of the Galician upwelling (Valdés et al. 2007). In turn, regarding long-term trends in chl a, Bode et al. (2009) did not identify any evidence for significant change at 2 locations, in Galicia and the central Cantabrian Sea, over the past 10 to 20 yr. Along the Basque coast, a significant $(p<0.05)$ slight decrease in surface chl a was observed from 1986-2008 (Revilla et al. 2010; Fig. 12). This decrease is consistent with the concep- tual model of Richardson \& Schoeman (2004) that describes the effect of increasing temperature in marine waters with seasonal stratification and limited nutrient concentrations, such as that within the southeastern part of the Bay of Biscay. In turn, when studying the water column (0 to $100 \mathrm{~m}$ water depth), a significant chl a increase was found for the period 1986-2009, especially in the photic layer (0 to $50 \mathrm{~m}$ ) with values of $6.2 \times 10^{-3} \mu \mathrm{g} \mathrm{l}^{-1} \mathrm{yr}^{-1}$ (M. Revilla pers. comm.). In this period, the deepening of the subsurface maximum of chlorophyll was from $10 \mathrm{~m}$ in 1986 to $30 \mathrm{~m}$ in the years 2000-2009, explaining this incoherency between the decrease in surface and the increase in subsurface layers (M. Revilla pers. comm.).

Offshore in the Bay of Biscay, a 10 yr study of the optical properties derived from the SeaWIFS sensor has suggested a significant increase in chl a within this area (Vantrepotte \& Mélin 2010). Actually, the longest time series (from 1957) covering oceanic waters is the continuous plankton recorder (CPR) survey line, linking the UK to Galicia. The phytoplankton colour index indicates a clear increase in primary productivity in the areas that encompass offshore waters in the Bay of Biscay (Edwards et al. 2009). This increase in primary productivity does not appear to have been transferred to the higher trophic levels, as CPR data suggest that zooplankton concentration is stable or has declined, as also observed in coastal time series (Valdés et al. 2007).

\subsubsection{Predictions in plankton changes}

Global models are in agreement in forecasting a long-term decrease of primary production in the North Atlantic, including the Bay of Biscay (Steinacher et al. 2009). However, such global models generally do not perform well in coastal areas such as those of the Bay of Biscay (Steinacher et al. 2009). On the other hand, higher-resolution regional models also predict an increase in the total annual stratified days for the bay (Lowe et al. 2009), which would result in a decrease in nutrients and net primary production. Such forecasts must be considered with caution, since in the Bay of Biscay, nutrient concentration is also heavily dependent upon river discharges, and at present no regional models on variation in river discharges for the overall area are available.

\subsection{Fish stocks}

\subsubsection{Relationships between climate and fishes}

The population dynamics of practically all species of commercial interest within the Bay of Biscay are influ- 


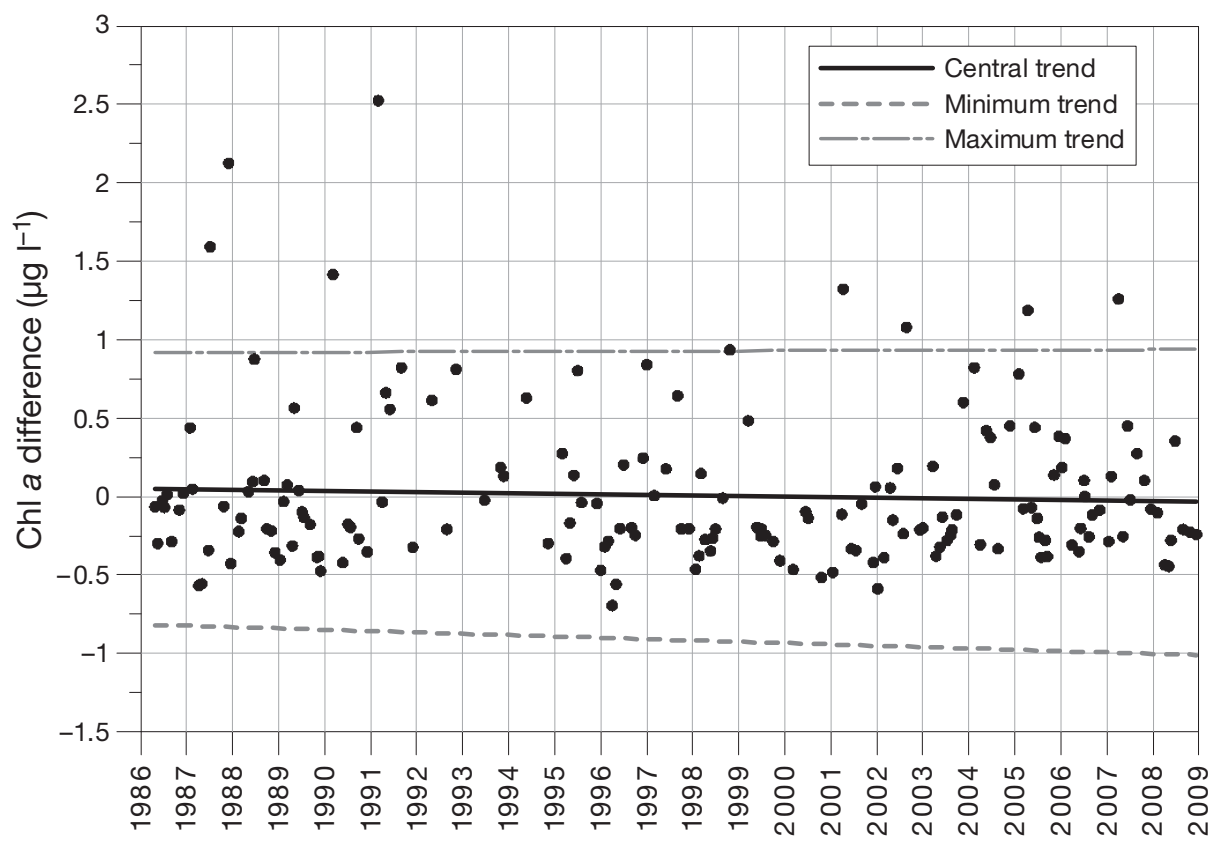

Fig. 12. Temporal trend of sea surface chlorophyll $a$ at Station D2 $\left(43^{\circ} 27^{\prime} \mathrm{N}, 1^{\circ} 55^{\prime} \mathrm{W}\right.$; offshore waters from the Basque Country, southeastern part of the Bay of Biscay), from 1986-2008. Values presented are the difference between the measured data and the data estimated for an average year (for details, see Revilla et al. 2010)

enced by climate. Factors such as the NAO (albacore, Arregui et al. 2006; sardine, Alheit \& Hagen 1997; several fish stocks, mammals and seabirds, Hemery et al. 2008), EA pattern (anchovy, Borja et al. 2008); temperature anomaly (hake, Fernandes et al. 2010), upwelling strength (anchovy, Borja et al. 2008), turbulence (anchovy, mackerel and hake, Borja et al. 1998, 2002, Allain et al. 2007, Fernandes et al. 2010), river discharge (anchovy, Planque \& Buffaz 2008) and Ekman transport (anchovy, Irigoien et al. 2008) have been shown to have significant effects on the recruitment or abundance of these species.

From bottom survey time series, Poulard \& Blanchard (2005) found that the abundance of fish species with a wide latitudinal distribution (mainly subtropical) has increased in the Bay of Biscay, whereas the abundance of temperate and least widely distributed species has decreased. In a study focusing on flatfish in the area of Bay of Villaine, Désaunay et al. (2006) found a decrease in northern spawners such as plaice and dab, whereas southern spawners, such as wedge sole, increased.

One of the best examples showing the links between climate, oceanography and fish recruitment within the Bay of Biscay is that of anchovy (Borja et al. 2008). These authors demonstrated that $55 \%$ of the recruitment variability of this species can be explained by upwelling over the spawning area (southeastern part of the bay), with the upwelling intensity related to the EA pattern (Fig. 13). The conceptual understanding of the relationship suggests that negative EA periods are associated with northeasterly wind circulation, which produces weak upwelling over the continental shelf. This pattern results in hydrodynamic stability over the area, probably leading to adequate food availability. In turn, positive EA periods are associated with southwesterly winds and downwelling over the continental shelf; this leads to the dispersion of anchovy food and larvae, together with increasing mortality.

Recently, data mining techniques have been used to extract the combinations of climatic factors that influence the recruitment of anchovy and hake (Fernandes et al. 2010). Anchovy recruitment is influenced mainly by the upwelling index, wind direction and turbulence; for hake, temperature anomaly and turbulence are the factors emerging from the analysis. Understanding how climate change will influence local variations in upwelling strength, wind direction or turbulence will require further development of the regional climate models. On the other hand, it could be assumed that a temperature increase should generally benefit hake recruitment. However, we must be aware of the risks of linear extrapolations, as both the analysis of past data and the extrapolations are influenced by abrupt regime shifts (Reid et al. 2001, Beaugrand 2004). Such regime shifts have an influence on fish distribution, even those with wide migrations (Dufour et al. 2010). Furthermore, the benefit of the temperature increase for hake would not be linear, because, as for any other species, there is a maximum temperature over which further increases are detrimental (Mantzouni \& MacKenzie 2010). 


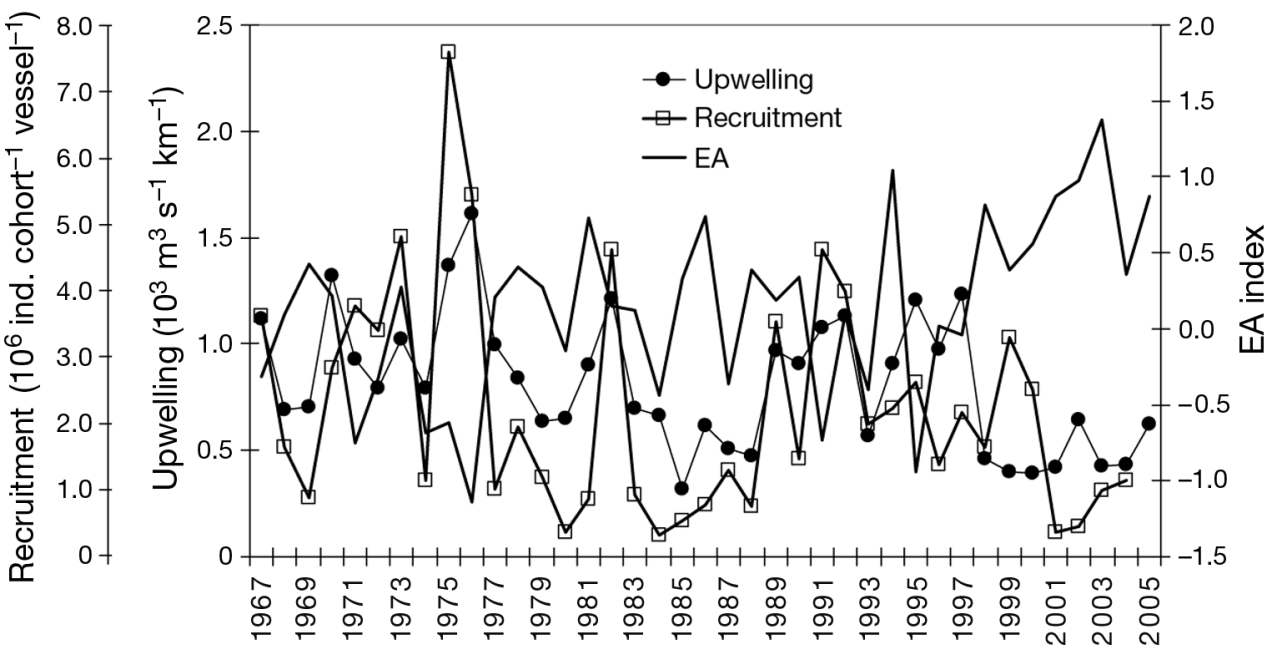

Fig. 13. Comparison between the total annual upwelling (March to July), Eastern Atlantic (EA) index (March to July) and the Bay of Biscay anchovy recruitment index, between 1967 and 2005 (modified from Borja et al. 2008)

\subsubsection{Predictions on fish changes}

The projected increase in sea temperature over the Bay of Biscay (section 2.3.), a weakening in the Atlantic thermohaline circulation and an increase in stratification, together with other changes described in previous sections, will change the geographical distribution of species (Clemmesen et al. 2007). These changes will result in: (1) shifts of fish populations, with the invasion of alien species and disappearance of native species; and (2) direct influence on survivorship, reproduction, dispersal, fertility and the behaviour of individuals and, thus, on abundance and distribution, as also stated for other marine areas (Drinkwater et al. 2010).

Studies focusing on diadromous fish species (Lassalle \& Rochard 2009) have predicted that river basins in the Bay of Biscay may no longer be suitable for a number of species (e.g. Petromyzon marinus, Salmo salar, Lampetra fluviatilis, Alosa alosa, Platichthys flesus). Although it is very difficult to judge at a global level who the main losers and winners will be from changes in fish and fisheries as a result of climate change, Brander (2010) provided some recommendations on short-, medium- and long-term management for fisheries. These can be summarised in an adaptation to changing climate, future monitoring and research, all of which must be linked closely to responsive, flexible and reflexive management systems.

\section{CONCLUDING REMARKS}

The trend in annual air temperature throughout the 20th century (1901-2005) in the northern region of the Iberian Peninsula was, within a $95 \%$ interval, between 0.09 and $0.16^{\circ} \mathrm{C} \mathrm{dec}^{-1}$. This trend was much higher during the period 1973-2005, with an estimated increase of $0.51{ }^{\circ} \mathrm{C} \mathrm{dec}-1$. Projections from regional climate models for the 21st century, under GHG emission scenarios, indicate warming of surface air over the Basque Country. In particular, heat wave episodes will increase in duration, and the 90th percentile of daily maximum temperature is expected to increase during summer by $3 \pm 0.9^{\circ} \mathrm{C}$. Air surface warming will increase the temperature of the upper sea surface layers, especially in the coastal areas. According to the projections, the temperature of the upper $100 \mathrm{~m}$ of the water column in the Bay of Biscay will increase by between 1.5 and $2.05^{\circ} \mathrm{C}$ during the 21 st century; this is in agreement with the SST warming trend since the 1970s. The consequence of such warming is thermal expansion of the ocean and, hence, SLR. In particular, the projections (A1B and A2 scenarios) of SLR in the bay indicate an increase of between 29 and $49 \mathrm{~cm}$ from 2001-2099, as a result of regional thermal expansion and global ice melt. This is in agreement with the long-term tide gauge records and satellite-derived measurements in the Bay of Biscay, consistently showing an SLR throughout the 20th century.

SLR is predicted to flood 111 ha of the supralittoral area of the Gipuzkoan coast, concentrated within lowlying areas within the inner estuaries, whilst extreme waves predicted with a 50 yr return period will mainly affect sandy beaches, harbours and some urban areas. Wetlands and saltmarshes are expected to be affected to a lesser degree, since their dynamic response in terms of accretion may balance the future rate of SLR. Future research should focus on modelling the estuarine sediment morphodynamics according to the expected sea level by the end this century. Sandy beaches, which are expected to undergo mean shoreline retreats of between 25 and $40 \%$ of their width, are 
identified as one of the main vulnerable littoral elements. For artificial surfaces, the expected main impacts are erosion or failure of coastal defences, flooding of urban areas in estuaries, damage to drainage systems and the salinisation of groundwater. The projected warming of the air and sea along the Basque coast might also interact negatively with SLR, e.g. through loss of coastal biodiversity, especially for those estuarine populations of species with narrow niches, with limited dispersal potential and with artificially fragmented habitat.

The future impacts of ocean warming on pelagic and coastal water ecosystems are subjected to different positive and negative feedbacks. The distribution and dynamics of most of the biological elements reviewed (i.e. chl $a$, plankton and benthic species communities and populations, natural habitats, fisheries) are affected by ocean-climatic variability. Observations of biological indicators within the study area are somewhat short term $(<25$ yr) or 'snapshots', which makes it difficult to extract any long-term trends. However, if the Atlantic thermohaline circulation is weakened and stratification is increased during the 21st century, as expected by some projections, these changes will result in shifts of fish populations, invasion by alien species, disappearance of some native species, and direct influence on survivorship, reproduction, dispersal, fertility and behaviour of individuals and, thus, on abundance and distribution. The projections for the 21st century over this area indicate a slight decrease in the mean precipitation $\left(-0.7 \pm 0.3 \% \mathrm{dec}^{-1}\right)$ and a slight increase in extreme daily rainfall $(10 \%)$. This pattern may have implications for those marine species dwelling or spawning in estuarine waters. In particular, the regime of flood events in the coast of the area studied is expected to change slightly and the estuarine ecosystems will be subjected to more extremes, e.g. from lower streamflow (during dry spells), to higher hydrodynamic, turbid (suspended matter charged) waters (during heavy rainfall events). Future research should focus on projecting changes on current circulation, upwelling/downwelling, climatic indices (i.e. EA, NAO), wave climate and acidification within the bay, in order to better assess the future potential impacts on pelagic and coastal water ecosystems.

Acknowledgements. This study was supported by the Department of Environment, Regional Planning, Agriculture and Fisheries (DERPAF) of the Basque Government (K-Egokitzen and EKLIMA21 projects, Etortek Funding Program); likewise, by the Ministry of Environment and Rural and Marine Environment of the Spanish Government (Project Ref.: 0.39/ SGTB/2007/4.1), and the Ministry of Science and Innovation (Project Ref.: CGL2008-03321). We acknowledge the contribution of M. Collins (School of Ocean and Earth Science, University of Southampton and AZTI-Tecnalia), A. Fontán and
M. González (AZTI-Tecnalia) for providing useful comments; I. Galparsoro and J. M. Garmendia (AZTI-Tecnalia) for providing data for generating the $Z$. noltii habitat model; and F. J. Méndez (Universidad de Cantabria) for providing wave height scenarios. This is contribution 529 from AZTI-Tecnalia Marine Research Division.

\section{LITERATURE CITED}

Abanades JC, Cuadrat JM, de Castro M, Fernández F and others (2007) El cambio climático en España. Estado de situación. Spanish Ministry of Environment, Madrid

Acinas RA (2002) Cambio climático y subida del nivel medio del mar. Impacto sobre la costa. Ing Territ 61:60-67

Alcamo J, Moreno JM, Nováky B, Bindi M and others (2007) Europe. In: Parry ML, Canziani OF, Palutikof JP, van der Linden PJ, Hanson CE (eds) Climate change 2007: impacts, adaptation and vulnerability. Contribution of Working Group II to the Fourth Assessment Report of the Intergovernmental Panel on Climate Change. Cambridge University Press, Cambridge, p 541-580

Alcock R (2003) The effects of climate change on rocky shore communities in the Bay of Biscay, 1895-2050. PhD thesis, University of Southampton

Alheit J, Hagen E (1997) Long-term climate forcing of European herring and sardine populations. Fish Oceanogr 6:130-139

Allain G, Petitgas P, Lazure P, Grellier P (2007) Biophysical modelling of larval drift, growth and survival for the prediction of anchovy (Engraulis encrasicolus) recruitment in the Bay of Biscay (NE Atlantic). Fish Oceanogr 16:489-505

Allan RP, Soden BJ (2008) Atmospheric warming and the amplification of precipitation extremes. Science 321: 1481-1484

Alvarez I, Gómez-Gesteira M, deCastro M, Gómez-Gesteira JL, Dias JM (2010) Summer upwelling frequency along the western Cantabrian coast from 1967 to 2007. J Mar Syst 79:218-226

Araújo IB, Pugh DT (2008) Sea levels at Newlyn 1915-2005: analysis of trends for future flooding risks. J Coast Res 24:203-212

- Aravena G, Villate F, Iriarte A, Uriarte I, Ibáñez B (2009a) Influence of the North Atlantic Oscillation (NAO) on climatic factors and estuarine water temperature on the Basque coast (Bay of Biscay): comparative analysis of three seasonal NAO indices. Cont Shelf Res 29:750-758

> Aravena G, Villate F, Uriarte I, Iriarte A, Ibáñez B (2009b) Response of Acartia populations to environmental variability and effects of invasive congenerics in the estuary of Bilbao, Bay of Biscay. Estuar Coast Shelf Sci 83:621-628

Arregui I, Arrizabalaga H, Kirby DS, Martin-Gonzalez JM (2006) Stock-environment-recruitment models for North Atlantic albacore (Thunnus alalunga). Fish Oceanogr 15: 402-412

Bárdossy A, Caspary HJ (1990) Detection of climate change in Europe by analysing European atmospheric circulation patterns from 1881 to 1989. Theor Appl Climatol 42: 155-167

Barry RG, Chorley RJ (2003) Atmosphere, weather, and climate, 8th edn. Routledge, London

Beaugrand G (2004) The North Sea regime shift: evidence, causes, mechanisms and consequences. Prog Oceanogr 60:245-262

Bindoff NL, Willebrand J, Artale V, Cazenave A and others (2007) Observations: oceanic climate change and sea level. In: Solomon S, Qin D, Manning M, Chen Z and oth- 
ers (eds) Climate change 2007: the physical science basis. Contribution of Working Group I to the Fourth Assessment Report of the Intergovernmental Panel on Climate Change. Cambridge University Press, Cambridge, p 387-429

Bode A, Anadón R, Cabanas JM, Carballo R and others (2009) Year-to-year variability in inorganic nutrients, primary production and phytoplankton biomass off NW Spain from 1990 to 2007. ICES CM 2009/ D:13 ICES, Copenhagen

Borja A (1987) Cartografía, evaluación de la biomasa y arribazones del alga Gelidium sesquipedale (Clem.) Born. et Thur. en la costa guipuzcoana (N España). Invest Pesq 51:199-224

Borja A (1994) Factores ambientales que influyen en al generación, desprendimiento de biomasa, crecimiento y producción en praderas naturales de Gelidium sesquipedale (Clem.) Born. et Thur. en el País Vasco ( $\mathrm{N}$ de España). Sci Mar 58:251-260

Borja A, Gorostiaga JM (1990) Distribución geográfica de Saccorhiza polyschides (Light.) Batt. en la costa vasca. Su posible relación con la temperatura. Actas $6^{\circ}$ Simposio Ibérico Estudios Bentos Marino, Palma de Mallorca 1, p $1-8$

Borja A, Fernández JA, Orive E (1982) Estudio sobre zonación en el intermareal rocoso del entorno del estuario del Nervión. Bull Cent Etud Rech Sci Biarritz 14:55-82

Borja A, Uriarte A, Egaña J, Motos L, Valencia V (1998) Relationships between anchovy (Engraulis encrasicolus) recruitment and environment in the Bay of Biscay (19671996). Fish Oceanogr 7:375-380

Borja Á, Egaña J, Valencia V, Franco F, Castro R (2000) 1947-1997, estudio y validación de una serie de datos diarios de temperatura del agua del mar en San Sebastián, procedente de su Aquarium. Ozeanografika 3:139-152

Borja A, Uriarte A, Egaña J (2002) Environmental factors and recruitment of mackerel, Scomber scombrus L. 1758, along the north-east Atlantic coasts of Europe. Fish Oceanogr 11:116-127

Borja A, Aguirrezabalaga F, Martínez J, Sola JC, GarcíaArberas L, Gorostiaga JM (2004a) Benthic communities, biogeography and resources management. In: Borja A, Collins M (eds) Oceanography and marine environment of the Basque Country. Elsevier Oceanogr Ser 70: 455-492

Borja A, Franco J, Valencia V, Bald J, Muxika I, Belzunce MJ, Solaun O (2004b) Implementation of the European Water Framework Directive from the Basque Country (northern Spain): a methodological approach. Mar Pollut Bull 48: 209-218

Borja Á, Muxika I, Franco J (2006) Long-term recovery of softbottom benthos following urban and industrial sewage treatment in the Nervión estuary (southern Bay of Biscay). Mar Ecol Prog Ser 313:43-55

Borja A, Fontán A, Sáenz J, Valencia V (2008) Climate, oceanography, and recruitment: the case of the Bay of Biscay anchovy (Engraulis encrasicolus). Fish Oceanogr 17:477-493

Borja A, Muxika I, Rodríguez JG (2009) Paradigmatic responses of marine benthic communities to different anthropogenic pressures, using M-AMBI, within the European Water Framework Directive. PSZNI: Mar Ecol 30: 214-227

Brander K (2010) Impacts of climate change on fisheries. J Mar Syst 79:389-402

Brunet M, Jones PD, Sigró J, Saladié O and others (2007) Temporal and spatial temperature variability and change over Spain during 1850-2005. J Geophys Res 112:D12117 doi:10.1029/2006JD008249

Bruun P (1988) The Bruun rule of erosion by sea-level rise: a discussion of large-scale two- and three-dimensional usages. J Coast Res 4:627-648

Caballero A, Pascual A, Dibarboure G, Espino M (2008) Sea level and eddy kinetic energy variability in the Bay of Biscay, inferred from satellite altimeter data. J Mar Syst 72 : $116-134$

Castro-Díez Y, Pozo-Vázquez D, Rodrigo FS, Esteban-Parra MJ (2002) NAO and winter temperature variability in southern Europe. Geophys Res Lett 29:1160 doi: 10.1029/ 2001GL014042

Cazenave A, Nerem RS (2004) Present-day sea level change: observations and causes. Rev Geophys 42:RG3001 doi: 10.1029/2003RG000139

> Cazenave A, Dominh K, Guinehut S, Berthier E and others (2009) Sea level budget over 2003-2008: a reevaluation from GRACE space gravimetry, satellite altimetry and Argo. Global Planet Change 65:83-88

Cearreta A, Irabien MJ, Pascual A (2004) Human activities along the Basque coast during the last two centuries: geological perspective of recent anthropogenic impact on the coast and its environmental consequences. In: Borja A, Collins M (eds) Oceanography and marine environment of the Basque Country. Elsevier Oceanogr Ser 70:27-50

Cendrero A, Sánchez-Arcilla A, Zazo C (2005) Impacts on coastal areas. In: Moreno JM (ed) Impacts of the climatic change in Spain. Ministry of Environment, Madrid, p 451-504

Christensen JH, Carte TR, Rummukainen M, Amanatidis G (2007a) Evaluating the performance and utility of regional climate models: the PRUDENCE project. Clim Change 81:2-6

Christensen JH, Hewitson B, Busuioc A, Chen A and others (2007b) Regional climate projections. In: Solomon S, Qin D, Manning M, Chen Z and others (eds) Climate change: the physical science basis. Contribution of Working Group I to the Fourth Assessment Report of the Intergovernmental Panel on Climate Change. Cambridge University Press, Cambridge, p 847-940

Church JA, White NJ (2006) A 20th century acceleration in global sea-level rise. Geophys Res Lett 33:L01602 doi: 10.1029/2005GL024826

Church JA, White NJ, Coleman R, Lambeck K, Mitrovica JX (2004) Estimates of the regional distribution of sea level rise over the 1950-2000 period. J Clim 17:2609-2625

Chust G, Galparsoro I, Borja A, Franco J, Beltrán B, Uriarte A (2007) Detección de cambios recientes en la costa vasca mediante ortofotografía. Lurralde 30:59-72

Chust G, Borja Á, Liria P, Galparsoro I, Marcos M, Caballero A, Castro R (2009) Human impacts overwhelm the effects of sea-level rise on Basque coastal habitats (N Spain) between 1954 and 2004. Estuar Coast Shelf Sci 84:453-462

Chust G, Caballero A, Marcos M, Liria P, Hernández C, Borja Á (2010) Regional scenarios of sea level rise and impacts on Basque (Bay of Biscay) coastal habitats, throughout the 21st century. Estuar Coast Shelf Sci 87:113-124

Clemmesen C, Potrykus A, Schmidt J (2007) Climate change and European fisheries. European Parliament, Directorate General Internal Policies of the Union, Brussels, p 1-133

Cooper JAG, Pilkey OH (2004) Sea level rise and shoreline retreat: time to abandon the Bruun rule. Glob Planet Change 43:157-171

Costanza R, d'Arge R, de Groot R, Farber S and others (1997) The value of the world's ecosystem services and natural capital. Nature 387:253-260

Crooks S (2004) The effect of sea-level rise on coastal geomorphology. Ibis 146:18-20

Davidson-Arnott RGD (2005) Conceptual model of the effects 
of sea level rise on sandy coasts. J Coast Res 21:1166-1172 Debernard JB, Røed LP (2008) Future wind, wave and storm surge climate in the northern seas: a revisit. Tellus Ser A Dyn Meteorol Oceanogr 60:427-438

deCastro M, Martín-Vide J, Alonso S (2005) The climate of Spain: past, present and scenarios for the 21st century. In Moreno JM (ed) A preliminary assessment of the impacts in Spain due to the effects of climate change. Ministry of the Environment, Madrid, p 1-64

deCastro M, Gómez-Gesteira M, Alvarez I, Cabanas JM, Prego R (2008a) Characterization of fall-winter upwelling recurrence along the Galician western coast (NW Spain) from 2000 to 2005: dependence on atmospheric forcing. J Mar Syst 72:145-158

deCastro M, Gómez-Gesteira M, Lorenzo MN, Alvarez I, Crespo AJC (2008b) Influence of atmospheric modes on coastal upwelling along the western coast of the Iberian Peninsula, 1985 to 2005. Clim Res 36:169-179

deCastro M, Gómez-Gesteira M, Alvarez I, Gómez-Gesteira JL (2009) Present warming within the context of coolingwarming cycles observed since 1854 in the Bay of Biscay. Cont Shelf Res 29:1053-1059

> Defeo O, McLachlan A, Schoeman DS, Schlacher TA and others (2009) Threats to sandy beach ecosystems: a review. Estuar Coast Shelf Sci 81:1-12

De-Luis M, González-Hidalgo JC, Longares LA, Stepánek P (2009) Seasonal precipitation trends in the Mediterranean Iberian Peninsula in second half of 20th century. Int J Climatol 29:1312-1323

> Denslow JS, Battaglia LL (2002) Stand composition and structure across a changing hydrologic gradient: Jean Lafitte National Park, Louisiana, USA. Wetlands 22:738-752

Déqué M, Rowell DP, Lüthi D, Giorgi F and others (2007) An intercomparison of regional climate simulations for Europe: assessing uncertainties in model projections. Clim Change 81:53-70

> DeSantis LRG, Bhotika S, Williams K, Putz FE (2007) Sealevel rise and drought interactions accelerate forest decline on the Gulf Coast of Florida, USA. Glob Change Biol 13:2349-2360

Désaunay Y, Guérault D, Le Pape O, Poulard JC (2006) Changes in occurrence and abundance of northern/southern flatfishes over a 20-year period in a costal nursery area (Bay of Vilaine) and on the eastern continental shelf of the Bay of Biscay. Sci Mar 70 (Suppl 1):193-200

- Devoy RJN (2008) Coastal vulnerability and the implications of sea-level rise for Ireland. J Coast Res 24:325-341

Díez I, Secilla A, Santolaria A, Gorostiaga JM (2000) The north coast of Spain. In: Sheppard C (ed) Seas at the millennium: an environmental evaluation, Vol 1. Pergamon Press, Amsterdam, p 135-150

Domingues CM, Church JA, White NJ, Gleckler PJ, Wijffels SE, Barker PM, Dunn JR (2008) Improved estimates of upper-ocean warming and multi-decadal sea-level rise. Nature 453:1090-1093

> Douglas BC (1992) Global sea level acceleration. J Geophys Res 97:12699-12706

Drinkwater KF, Beaugrand G, Kaeriyama M, Kim S and others (2010) On the processes linking climate to ecosystem changes. J Mar Syst 79:374-388

Dufour F, Arrizabalaga H, Irigoien X, Santiago J (2010) Climate impacts on albacore and bluefin tunas migrations phenology and spatial distribution. Prog Oceanogr 86: 283-290

> Dupuis H, Michel D, Sottolichio A (2006) Wave climate evolution in the Bay of Biscay over two decades. J Mar Syst 63:105-114
Edwards M, Beaugrand G, John AWG, Johns DG, Licandro P, McQuatters-Gollop A, Reid PC (2009) Ecological status report: results from the CPR survey 2007/2008. SAHFOS Tech Rep 6. SAHFOS, Plymouth, p 1-12 ISSN 1744-0

Ericson JP, Vorosmarty CJ, Dingman SL, Ward LG, Meybeck $M$ (2006) Effective sea-level rise and deltas: causes of change and human dimension implications. Glob Planet Change 50:63-82

European Environment Agency (2006) The changing faces of Europe's coastal areas. EEA Rep No 6/2006. European Environment Agency, Copenhagen

Fahrig L (2003) Effects of habitat fragmentation on biodiversity. Annu Rev Ecol Evol Syst 34:487-515

> Fernandes JA, Irigoien X, Goikoetxea N, Lozano JA, Inza I, Pérez A, Bode A (2010) Fish recruitment prediction, using robust supervised classification methods. Ecol Model 221: 338-352

> Ferrer L, Fontán A, Mader J, Chust G and others (2009) Low-salinity plumes in the oceanic region of the Basque Country. Cont Shelf Res 29:970-984

FitzGerald DM, Fenster MS, Argow BA, Buynevich IV (2008) Coastal impacts due to sea-level rise. Annu Rev Earth Planet Sci 36:601-647

Fontán A, Valencia V, Borja A, Goikoetxea N (2008) Oceanometeorological conditions and coupling in the southeastern Bay of Biscay, for the period 2001-2005: a comparison with the past two decades. J Mar Syst 72:167-177

Frías MD, Fernández J, Sáenz J, Rodríguez-Puebla C (2005) Operational predictability of monthly average maximum temperature over the Iberian Peninsula using DEMETER simulations and downscaling. Tellus Ser A Dyn Meteorol Oceanogr 57:448-463

Frías MD, Herrera S, Cofiño AS, Gutiérrez JM (2010) Assessing the skill of precipitation and temperature seasonal forecasts in Spain: windows of opportunity related to ENSO events. J Clim 23:209-220

Friedrichs CT, Perry JE (2001) Tidal salt marsh morphodynamics: a synthesis. J Coast Res Spec Issue 27:7-37

> Gallego MC, García JA, Vaquero JM, Mateos VL (2006) Changes in frequency and intensity of daily precipitation over the Iberian Peninsula. J Geophys Res 111:D24105 doi: 10.1029/2006JD007280

Galparsoro I, Borja Á, Legorburu I, Hernández C, Chust G, Liria P, Uriarte A (2010) Morphological characteristics of the Basque continental shelf (Bay of Biscay, northern Spain); their implications for Integrated Coastal Zone Management. Geomorphology 118:314-329

Garbutt RA, Reading CJ, Wolters M, Gray AJ, Rothery P (2006) Monitoring the development of intertidal habitats on former agricultural land after the managed realignment of coastal defences at Tollesbury, Essex, UK. Mar Pollut Bull 53:155-164

García-Soto C, Pingree RD, Valdés L (2002) Navidad development in the southern Bay of Biscay: climate change and swoddy structure from remote sensing and in situ measurements. J Geophys Res 107:3118 doi:10.1029/ 2001JC001012

Garmendia M, Borja A, Muxika I (2008) Long-term environmental, climatic and anthropogenic factors affecting subtidal soft-bottom benthic communities, within the Basque coast. Rev Invest Mar 2:1-28

Gesch DB (2009) Analysis of lidar elevation data for improved identification and delineation of lands vulnerable to sealevel rise. J Coast Res Spec Issue 53:50-59

Goikoetxea N, Borja Á, Egaña J, Fontán A, González M, Valencia V (2009) Trends and anomalies in sea surface temperature, observed over the last 60 years, within the 
southeastern Bay of Biscay. Cont Shelf Res 29:1060-1069 Gómez-Gesteira M, de Castro M, Alvarez I, Gómez-Gesteira JL (2008) Coastal sea surface temperature warming trend along the continental part of the Atlantic Arc (1985-2005). J Geophys Res 113:C04010 doi: 10.1029/2007JC004315

González M, Uriarte A, Fontán A, Mader J, Gyssels P (2004) Marine dynamics. In: Borja A, Collins M (eds) Oceanography and marine environment of the Basque Country. Elsevier Oceanogr Ser 70:133-157

González M, Mader J, Fontán A, Uriarte A, Ferrer L (2008) Análisis de la tendencia de la temperatura superficial del agua del mar en Donostia-San Sebastián a partir del estudio de la serie del Aquarium (1946-2007). Rev Invest Mar 4:1-7

> González-Pola C, Lavín A, Vargas-Yáñez M (2005) Intense warming and salinity modification of intermediate water masses in the southeastern corner of the Bay of Biscay for the period 1992-2003. J Geophys Res 110:C05020 doi: 10.1029/2004JC002367

Goubanova K, Li L (2007) Extremes in temperature and precipitation around the Mediterranean basin in an ensemble of future climate scenario simulations. Glob Planet Change $57: 27-42$

- Grevemeyer I, Herbert R, Essen HH (2000) Microseismological evidence for a changing wave climate in the northeast Atlantic Ocean. Nature 408:349-351

Habitats Directive (1992) Council Directive 92/43/EEC of 21 May 1992 on the conservation of natural habitats and of wild fauna and flora. European Union, Brussels

> Haigh I, Nicholls R, Wells N (2009) Mean sea level trends around the English Channel over the 20th century and their wider context. Cont Shelf Res 29:2083-2098

> Halpern BS, Walbridge S, Selkoe KA, Kappel CV and others (2008) A global map of human impact on marine ecosystems. Science 319:948-952

Hemery G, D'Amico F, Castege I, Dupont B, D'Elbee J, Lalanne Y, Mouches C (2008) Detecting the impact of oceano-climatic changes on marine ecosystems using a multivariate index: the case of the Bay of Biscay (North Atlantic-European Ocean). Glob Change Biol 14:27-38

Hewitt CD (2005) The ENSEMBLES Project: providing ensemble-based predictions of climate changes and their impacts. EGGS Newsl 13:22-25

> Hu Y, Fu Q (2007) Observed poleward expansion of the Hadley circulation since 1979. Atmos Chem Phys 7: 5229-5236

- Hurrell JW (1995) Decadal trends in the North Atlantic Oscillation: regional temperatures and precipitation. Science 269:676-679

ICES (2004) The Annual ICES Ocean Climate Status Summary 2003/2004. ICES Cooperative Research Report, No. 269, Copenhagen

IPCC (Intergovernmental Panel on Climate Change) (2007) Climate change 2007: the physical science basis. Summary for policymakers. In: Alley R, Berntsen T, Bindoff NL, Chen Z and others (eds) Contribution of Working Group I to the Fourth Assessment Report of the Intergovernmental Panel on Climate Change, IPCC Secretariat, Geneva, p 1-21

Irigoien X, Cotano U, Boyra G, Santos M and others (2008) From egg to juvenile in the Bay of Biscay: spatial patterns of anchovy (Engraulis encrasicolus) recruitment in a nonupwelling region. Fish Oceanogr 17:446-462

> Jokiel PL, Brown EK (2004) Global warming, regional trends and inshore environmental conditions influence coral bleaching in Hawaii. Glob Change Biol 10:1627-1641

Khon VC, Mokhov II, Roeckner E, Semenov VA (2007) Regional changes of precipitation characteristics in north- ern Eurasia from simulations with global climate model. Glob Planet Change 57:118-123

Kiely G, Albetison JD, Parlange MB (1998) Recent trends in diurnal variation of precipitation at Valentia on the west coast of Ireland. J Hydrol (Amst) 207:270-279

Kirwan ML, Murray AB (2008a) Ecological and morphological response of brackish tidal marshland to the next century of sea level rise: Westham Island, British Columbia. Glob Planet Change 60:471-486

Kirwan ML, Murray AB (2008b) Tidal marshes as disequilibrium landscapes? Lags between morphology and Holocene sea level change. Geophys Res Lett 35:L24401 doi: 10.1029/2008GL036050

> Kirwan ML, Murray AB, Boyd WS (2008) Temporary vegetation disturbance as an explanation for permanent loss of tidal wetlands. Geophys Res Lett 35:L05403 doi: 10.1029/ 2007GL032681

> Koutsikopoulos C, Beillois P, Leroy C, Taillefer F (1998) Temporal trends and spatial structures of the sea surface temperature in the Bay of Biscay. Oceanol Acta 21:335-344

Lambeck K (2002) Sea level change from mid Holocene to recent time: an Australian example with global implications. In: Mitrovica JX, Vermeersen BLA (eds) Ice sheets, sea level and the dynamic Earth. Geodyn Ser 29. American Geophysical Union, Washington, DC, p 33-50

Lassalle G, Rochard E (2009) Impact of twenty-first century climate change on diadromous fish spread over Europe, North Africa and the Middle East. Glob Change Biol 15: 1072-1089

Lavín A, Valdés L, Gil J, Moral M (1998) Seasonal and interannual variability in properties of surface water off Santander, Bay of Biscay, 1991-1995. Oceanol Acta 21: 179-190

Lavín A, Valdés L, Sanchez F, Abaunza P and others (2006) The Bay of Biscay: the encountering of the ocean and the shelf. In: Robinson AR, Brink K (eds) The sea, Vol 14B. The global coastal ocean. Interdisciplinary Regional Studies and Syntheses. Harvard University Press, Cambridge, MA, p 933-1001

Leorri E, Cearreta A (2009) Recent sea-level changes in the southern Bay of Biscay: transfer function reconstructions from salt-marshes compared with instrumental data. Sci Mar 73:287-296

Leorri E, Horton BP, Cearreta A (2008) Development of a foraminifera-based transfer function in the Basque marshes, N. Spain: implications for sea-level studies in the Bay of Biscay. Mar Geol 251:60-74

Levitus S, Antonov J, Boyer T, Locarnini RA, Garcia HE, Mishonov AV (2009) Global ocean heat content 19552008 in light of recently revealed instrumentation problems. Geophys Res Lett 36:L07608 doi:10.1029/2008GL 037155

Lionello P, Galati MB (2008) Links of the significant wave height distribution in the Mediterranean Sea with the northern hemisphere teleconnection patterns. Adv Geosci $17: 13-18$

> Liria P, Garel E, Uriarte A (2009) The effects of dredging operations on the hydrodynamics of an ebb tidal delta: Oka Estuary, northern Spain. Cont Shelf Res 29:1983-1994

Llope M, Anadón R, Sostres JA, Viesca L (2007) Nutrients dynamics in the southern Bay of Biscay (1993-2003): winter supply, stoichiometry, long-term trends, and their effects on the phytoplankton community. J Geophys Res 112:C07029 doi:10.1029/2006JC003573

> Lopez-Bustins JA, Martin-Vide J, Sanchez-Lorenzo A (2008) Iberia winter rainfall trends based upon changes in teleconnection and circulation patterns. Glob Planet Change 
63:171-176

Lowe JA, Howard T, Pardaens A, Tinker J and others (2009) UK climate projections science report: marine and coastal projections. Met Office Hadley Centre, Exeter

Lu J, Vecchi GA, Reichler T (2007) Expansion of the Hadley cell under global warming. Geophys Res Lett 34:L06805 doi: 10.1029/2006GL028443

Mantzouni I, MacKenzie B (2010) Productivity responses of a widespread marine piscivore, Gadus morhua, to oceanic thermal extremes and trends. Proc R Soc Lond B Biol Sci 277:1867-1874

Marcos M, Gomis D, Monserrat S, Álvarez-Fanjul E, Pérez B, García-Lafuente J (2005) Consistency of long sea-level time series in the northern coast of Spain. J Geophys Res 110:C03008 doi:10.1029/2004JC002522

Marcos M, Woepelmann G, Bosch W, Savcenko R (2007) Decadal sea level trends in the Bay of Biscay from tide gauges, GPS and TOPEX. J Mar Syst 68:529-536

Marquiegui MA, Aguirrezabalaga F (2009) Colonization process by macrobenthic infauna after a managed coastal realignment in the Bidasoa estuary (Bay of Biscay, NE Atlantic). Estuar Coast Shelf Sci 84:598-604

- McGranahan DA, Balk D, Anderson B (2007) The rising tide: assessing the risks of climate change and human settlements in low elevation coastal zones. Environ Urban 19: $17-39$

Meehl GA, Stocker TF, Collins WD, Friedlingstein P and others (2007) Global climate projections. In: Solomon S, Qin D, Manning M, Chen Z and others (eds) Climate change 2007: the physical science basis. Contribution of Working Group I to the Fourth Assessment Report of the Intergovernmental Panel on Climate Change. Cambridge University Press, Cambridge, p 749-844

> Michael JA (2007) Episodic flooding and the cost of sea-level rise. Ecol Econ 63:149-159

Ministerio de Medio Ambiente (2006) Impactos en la costa española por efecto del cambio climático. Fase III. Estrategias frente al cambio climático en la costa. Oficina Española de Cambio Climático, Ministry of Environment, Madrid

Mokhov ER, Semenov VA, Khon VCh (2005) Extreme precipitation regimes in Northern Eurasia in the 20th century and their possible changes in the 21st century. Dokl Earth Sci 403:767-770

Moncho R (2009) Validación y calibración de los modelos regionales del clima para el estudio de las precipitaciones intensas del País Vasco. MSc thesis, Universitat de València

Moncho R, Chust G, Caselles V (2009) Análisis de la precipitación del País Vasco en el período 1961-2000 mediante reconstrucción espacial. Nimbus 23-24:149-170

Morris JT, Sundareshwar PV, Nietch CT, Kjerfve B, Cahoon DR (2002) Responses of coastal wetlands to rising sea level. Ecology 83:2869-2877

Mossmann VLF (2002) Análisis espacial y temporal de las tendencias de las precipitaciones en la España peninsular. $\mathrm{PhD}$ thesis, Universidad de León

Mosmann V, Castro A, Fraile R, Dessens J, Sánchez JL (2004) Detection of statistically significant trends in the summer precipitation of mainland Spain. Atmos Res 70:43-53

Nakicenovic N, Alcamo J, Davis G, de Vries B and others (2000) IPCC special report on emissions scenarios. Cambridge University Press, Cambridge

Nicholls RJ, Cazenave A (2010) Sea-level rise and its impact on coastal zones. Science 328:1517-1520

Nicholls RJ, Wong PP, Burkett VR, Codignotto JO and others (2007) Coastal systems and low-lying areas. In: Parry ML,
Canziani OF, Palutikof JP, van der Linden PJ, Hanson CE (eds) Climate change 2007: impacts, adaptation and vulnerability. Contribution of Working Group II to the Fourth Assessment Report of the Intergovernmental Panel on Climate Change. Cambridge University Press, Cambridge, p 315-356

Niehörster F, Fast I, Huebener H, Cubasch U (2008) The stream one ENSEMBLES projections of future climate change. Ensembles Tech Rep 3

O'Gorman PA, Schneider T (2009) The physical basis for increases in precipitation extremes in simulations of 21stcentury climate change. Proc Natl Acad Sci USA 106: 14773-14777

Pascual A, Rodríguez-Lázaro J (2006) Marsh development and sea level changes in the Gernika Estuary (southern Bay of Biscay): foraminifers as tidal indicators. Sci Mar 70: 101-117

Penduff T, Juza M, Brodeau L, Smith GC and others (2010) Impact of global ocean model resolution on sea-level variability with emphasis on interannual time scales. Ocean Sci 6:269-284

> Pérez FF, Pollard RT, Read JF, Valencia V, Cabanas M, Ríos AF (2000) Climatological coupling of the thermohaline decadal changes in Central Water of the Eastern North Atlantic. Sci Mar 64:347-353

Pérez L, Borja A, Rodríguez JG, Muxika I (2009) Long-term environmental, anthropogenic and climatic factors explaining spatial and temporal distribution of soft-bottom benthic communities within the Basque estuaries. Rev Invest Mar 14:1-22

Petus C, Chust G, Gohin F, Doxaran D, Froidefond JM, Sagarminaga Y (2010) Estimating turbidity and total suspended matter in the Adour River plume (South Bay of Biscay) using MODIS 250-m imagery. Cont Shelf Res 30: 379-392

Pfeffer WT, Harper JT, O'Neel S (2008) Kinematic constraints on glacier contributions to 21st-century sea-level rise. Science 321:1340-1343

- Pingree R (2005) North Atlantic and North Sea climate change: curl up, shut down, NAO and ocean colour. J Mar Biol Assoc UK 85:1301-1315

Planque B, Buffaz L (2008) Quantile regression models for fish recruitment-environment relationships: four case studies. Mar Ecol Prog Ser 357:213-223

Planque B, Fromentin JM, Cury P, Drinkwater KF, Jennings S, Perry RI, Kifani S (2010) How does fishing alter marine populations and ecosystems sensitivity to climate? J Mar Syst 79:403-417

Poulard JC, Blanchard F (2005) The impact of climate change on the fish community structure of the eastern continental shelf of the Bay of Biscay. ICES J Mar Sci 62:1436-1443

Poulter B, Halpin PN (2008) Raster modelling of coastal flooding from sea-level rise. Int J Geogr Inf Sci 22:167-182

> Pozo-Vázquez D, Esteban-Parra MJ, Rodrigo FS, Castro-Díez Y (2001) A study of NAO variability and its possible nonlinear influences on European surface temperature. Clim Dyn 17:701-715

Rahmstorf S (2007) A semi-empirical approach to projecting future sea-level rise. Science 315:368-370

Reeve DE, Karunarathna H (2009) On the prediction of longterm morphodynamic response of estuarine systems to sea level rise and human interference. Cont Shelf Res 29: 938-950

Reid PC, Borges MD, Svendsen E (2001) A regime shift in the North Sea circa 1988 linked to changes in the North Sea horse mackerel fishery. Fish Res 50:163-171

Reid PC, Fischer AC, Lewis-Brown E, Meredith MP and oth- 
ers (2009) Chapter 1. Impacts of the oceans on climate change. Adv Mar Biol 56:1-150

Revilla M, Borja Á, Fontán A, Franco J, González M, Valencia V (2010) A two-decade record of surface chlorophyll ' $a$ ' and temperature in offshore waters of the Basque country (southeastern Bay of Biscay). Rev Invest Mar 17:14-20

Richardson AJ, Schoeman DS (2004) Climate impact on plankton ecosystems in the Northeast Atlantic. Science 305:1609-1612

Rivas V, Cendrero A (1994) Human influence in a low-hazard coastal area: an approach to risk assessment and proposal of mitigation strategies. J Coast Res 12(Spec Issue 12): 289-298

- Rodrigo FS, Esteban-Parra MJ, Pozo-Vázquez D, Castro-Diez Y (1999) A 500-year precipitation record in southern Spain. Int J Climatol 19:1233-1253

Rogers JC (1997) North Atlantic storm track variability and its association to the North Atlantic Oscillation and climate variability of northern Europe. J Clim 10:1635-1647

Rummukainen M, Bergström S, Persson G, Rodhe J, Tjernström M (2004) The Swedish regional climate modelling programme, SWECLIM: a review. Ambio 33:176-182

Sáenz J, Zubillaga J, Rodríguez-Puebla C (2001a) Interannual winter temperature variability in the north of the Iberian Peninsula. Clim Res 16:169-179

Sáenz J, Rodríguez-Puebla C, Fernández J, Zubillaga J (2001b) Interpretation of interannual winter temperature variations over Southwestern Europe. J Geophys Res 106: 20641-20651

Sáenz J, Zubillaga J, Rodríguez-Puebla C (2001c) Interannual variability of winter precipitation in northern Iberian Peninsula. Int J Climatol 21:1503-1530

Schleupner C (2008) Evaluation of coastal squeeze and its consequences for the Caribbean island Martinique. Ocean Coast Manag 51:383-390

Schröter D, Cramer W, Leemans R, Prentice IC and others (2005) Ecosystem service supply and vulnerability to global change in Europe. Science 310:1333-1337

> Semenov VA, Bengtsson L (2002) Secular trends in daily precipitation characteristics: greenhouse gas simulation with a coupled AOGCM. Clim Dyn 19:123-140

Semmler T, Jacob D (2004) Modeling extreme precipitation events - a climate change simulation for Europe. Glob Planet Change 44:119-127

Serrano A, Mateos VL, García, JA (1999) Trend analysis of monthly precipitation over the Iberian Peninsula for the period 1921-1995. Phys Chem Earth B Hydrol Oceans Atmos 24: 85-90

Somavilla R, González-Pola C, Rodriguez C, Josey SA, Sánchez RF, Lavín A (2009) Large changes in the hydrographic structure of the Bay of Biscay after the extreme mixing of winter 2005. J Geophys Res 114:C01001 doi: 10.1029/2008JC004974

Southward AJ, Hawkins SJ, Burrows MT (1995) Seventy years' observations of changes in distribution and abundance of zooplankton and intertidal organisms in the western English Channel in relation to rising sea temperature. J Therm Biol 20:127-155

Southward AJ, Langmead O, Hardman-Mountford NJ, Aiken $\mathrm{J}$ and others (2005) Long-term oceanographic and ecological research in the western English Channel. Adv Mar Biol 47:1-105

Steinacher M, Joos F, Frolicher TL, Bopp L and others (2009) Projected 21st century decrease in marine productivity: a multi-model analysis. Biogeosci Discuss 6:7933-7981

> Tapiador FJ, Sánchez E, Gaertner MA (2007) Regional changes in precipitation in Europe under an increased greenhouse emissions scenario. Geophys Res Lett 34: L06701 doi: 10.1029/2006GL029035

The Wasa Group (1998) Changing waves and storm in the Northeast Atlantic? Bull Am Meteorol Soc 79:741-760

Titus JG, Anderson KE, Cahoon DR, Gesch DB, Gill SK, Gutierrez BT, Robert E (2009) Coastal sensitivity to sealevel rise: a focus on the Mid-Atlantic Region. A report by the U.S. Climate Change Science Program and the Subcommittee on Global Change Research, Washington, DC

Trigo RM, Osborn TJ, Corte-Real JM (2002) The North Atlantic Oscillation influence on Europe: climate impacts and associated physical mechanisms. Clim Res 20:9-17

> Trigo RM, Valente MA, Trigo IF, Miranda PMA, Ramos AM, Paredes D, García-Herrera R (2008) The impact of North Atlantic wind and cyclone trends on European precipitation and significant wave height in the Atlantic. Ann NY Acad Sci 1146:212-234

Uriarte A, Collins M, Cearreta A, Bald J, Evans G (2004) Sediment supply, transport and deposition: contemporary and Late Quaternary evolution. In: Borja A, Collins M (eds) Oceanography and marine environment of the Basque Country. Elsevier Oceanogr Ser 70:97-131

Valdés L, López-Urrutia A, Cabal J, Alvarez-Ossorio M and others (2007) A decade of sampling in the Bay of Biscay: What are the zooplankton time series telling us? Prog Oceanogr 74:98-114

Valencia V (1993) Estudio de la variación temporal de la hidrografía y el plancton en la zona nerítica frente a San Sebastián. Resultados 1988-1990. Inf Téc (Dep Agric Pesca Gobierno Vasco) 52:1-105

Valencia V, Borja A, Fontán A, Pérez FF, Ríos AF (2003) Temperature and salinity fluctuations in the Basque Coast (SE Bay of Biscay) from 1986 to 2000 related to the climatic factors. ICES Mar Sci Symp 219:340-342

Valencia V, Franco J, Borja Á, Fontán A (2004) Hydrography of the southeastern Bay of Biscay. In: Borja A, Collins M (eds) Oceanography and marine environment of the Basque Country. Elsevier Oceanogr Ser 70:159-194

Valencia V, Fontán A, Borja Á, Sáenz S (2009) Recent climatic changes in the SE Bay of Biscay affecting pelagic and coastal ecosystems. ICES CM 2009 / Theme Session G:11 (Abstract). Available at http://www.ices.dk/iceswork/asc/ 2009/Theme $\% 20$ sessions/Abstracts/Theme $\% 20$ Session $\%$ 20G\%20ed.pdf

Valle M, Borja Á, Galparsoro I, Garmendia JM, Chust G (2010) Estudio del hábitat idóneo para Zostera noltii y su modificación bajo un escenario de cambio climático en el estuario del Oka. Rev Invest Mar 17:1-12

Vantrepotte V, Mélin F (2010) Temporal variability in SeaWiFS derived apparent optical properties in European seas. Cont Shelf Res 30:319-334

> Villate F, Aravena G, Iriarte A, Uriarte I (2008) Axial variability in the relationship of chlorophyll $a$ with climatic factors and the North Atlantic Oscillation in a Basque coast estuary, Bay of Biscay (1997-2006). J Plankton Res 30:1041-1049

Vinchon C, Aubie S, Balouin Y, Closset L, Garcin M, Idier D, Mallet C (2009) Anticipate response of climate change on coastal risks at regional scale in Aquitaine and Languedoc Roussillon (France). Ocean Coast Manag 52:47-56

Visbeck MH, Hurrell JW, Polvani L, Cullen HM (2001) The North Atlantic oscillation: past, present, and future. Proc Natl Acad Sci USA 98:12876-12877

Wallace JM, Gutzler DS (1981) Teleconnections in the geopotential height field during the Northern Hemisphere winter. Mon Weather Rev 109:784-812

Webster TL, Forbes DL, Dickie S, Shreenan R (2004) Using topographic lidar to map flood risk from storm-surge 
events for Charlottetown, Prince Edward Island, Canada. Can J Rem Sens 30:64-76

Webster TL, Forbes DL, MacKinnon E, Roberts D (2006) Flood-risk mapping for storm-surge events and sea-level rise using lidar for southeast New Brunswick. Can J Rem Sens 32:194-211

Wilbanks TJ, Romero P, Lankao M, Bao F and others (2007) Industry, settlement and society. In: Parry ML, Canziani OF, Palutikof JP, van der Linden PJ, Hanson CE (eds) Climate change 2007: impacts, adaptation and vulnerability. Contribution of Working Group II to the Fourth Assessment Report of the Intergovernmental Panel on Climate Change. Cambridge University Press, Cambridge, p 357-390

Williams K, Ewel KC, Stumpf RP, Putz FE, Workman TW (1999) Sea-level rise and coastal forest retreat on the west coast of Florida, USA. Ecology 80:2045-2063

Williams K, MacDonald M, Sternberg L (2003) Interactions of

Submitted: April 12, 2010; Accepted: July 31, 2010 storm, drought, and sea-level rise on coastal forest: a case study. J Coast Res 19:1116-1121

Wolanski E, Chappell J (1996) The response of tropical Australian estuaries to a sea level rise. J Mar Syst 7:267-279

Wolf J, Woolf D (2005) Waves and climate change in the Sea of the Hebrides. Proc 15th Int Offshore Polar Eng Conf 3: 100-107

Woolf DK, Cotton PD, Challenor PG (2003) Measurements of the offshore wave climate around the British Isles by satellite altimeter. Philos Trans R Soc Lond A Math Phys Eng Sci 361:27-31

Wöppelmann G, Pouvreau N, Simon B (2006) Brest sea level record: a time series construction back to the early eighteenth century. Ocean Dyn 56:487-497

Zolina O, Kapala A, Simmer C, Gulev SK (2004) Analysis of extreme precipitation over Europe from different reanalyses: a comparative assessment. Glob Planet Change 44: $129-161$

Proofs received from author(s): August 22, 2011 